\title{
SOEP
}

SOEPpapers

on Multidisciplinary Panel Data Research

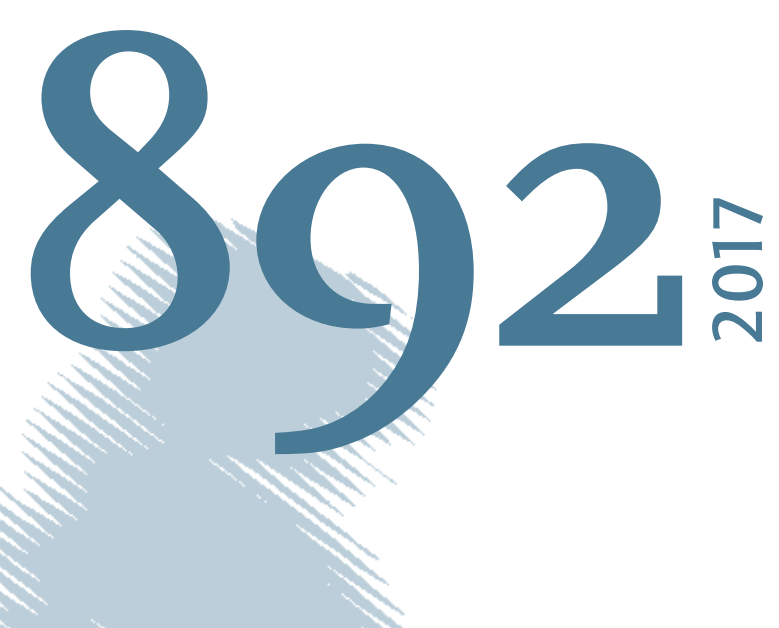

\section{The Performance of Immigrants in the German Labor Market}

Robert C. M. Beyer 
This series presents research findings based either directly on data from the German SocioEconomic Panel study (SOEP) or using SOEP data as part of an internationally comparable data set (e.g. CNEF, ECHP, LIS, LWS, CHER/PACO). SOEP is a truly multidisciplinary household panel study covering a wide range of social and behavioral sciences: economics, sociology, psychology, survey methodology, econometrics and applied statistics, educational science, political science, public health, behavioral genetics, demography, geography, and sport science.

The decision to publish a submission in SOEPpapers is made by a board of editors chosen by the DIW Berlin to represent the wide range of disciplines covered by SOEP. There is no external referee process and papers are either accepted or rejected without revision. Papers appear in this series as works in progress and may also appear elsewhere. They often represent preliminary studies and are circulated to encourage discussion. Citation of such a paper should account for its provisional character. A revised version may be requested from the author directly.

Any opinions expressed in this series are those of the author(s) and not those of DIW Berlin. Research disseminated by DIW Berlin may include views on public policy issues, but the institute itself takes no institutional policy positions.

The SOEPpapers are available at http://www.diw.de/soeppapers

\section{Editors:}

Jan Goebel (Spatial Economics)

Martin Kroh (Political Science, Survey Methodology)

Carsten Schröder (Public Economics)

Jürgen Schupp (Sociology)

Conchita D'Ambrosio (Public Economics, DIW Research Fellow)

Denis Gerstorf (Psychology, DIW Research Director)

Elke Holst (Gender Studies, DIW Research Director)

Frauke Kreuter (Survey Methodology, DIW Research Fellow)

Frieder R. Lang (Psychology, DIW Research Fellow)

Jörg-Peter Schräpler (Survey Methodology, DIW Research Fellow)

Thomas Siedler (Empirical Economics, DIW Research Fellow)

C. Katharina Spieß (Education and Family Economics)

Gert G. Wagner (Social Sciences)

ISSN: 1864-6689 (online)

German Socio-Economic Panel (SOEP)

DIW Berlin

Mohrenstrasse 58

10117 Berlin, Germany

Contact: soeppapers@diw.de

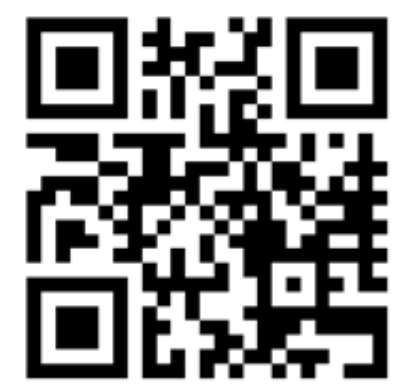




\title{
The Performance of Immigrants in the German Labor Market*
}

\author{
Robert C. M. Beyer ${ }^{\dagger}$
}

January 12, 2017

\begin{abstract}
This paper uses a large survey (SOEP) to update and deepen our knowledge about the labor market performance of immigrants in Germany. It documents that immigrant workers initially earn on average 20 percent less than native workers with otherwise identical characteristics. The gap is smaller for immigrants from advanced countries, with good German language skills, and with a German degree, and larger for others. The gap declines gradually over time but at a decreasing rate and much stronger for more recent cohorts. Less success in obtaining jobs with higher occupational autonomy explains half of the wage gap. Immigrants are initially less likely to participate in the labor market and more likely to be unemployed. While participation fully converges after 20 years, immigrants always remain more likely to be unemployed than the native labor force.
\end{abstract}

Keywords: migration, Germany, labor market, wages, unemployment, participation

JEL Classification: E24, F22, J15, J22, J31, J61

\footnotetext{
* The paper has partly been written at the European Department of the International Monetary Fund and a previous version is available as IMF Working Paper No. 16/6. The author wishes to thank Enrica Detragiache, Jerome Vandenbussche, Joana Pereira, Jean-Marc Natal, Zsoka Koczan, Nicola Fuchs-Schündeln and the participants of internal seminars at the IMF, the European Central Bank, and the German Council of Economic Experts, as well as the participants of the Brown Bag Seminar at Goethe University Frankfurt and of the CEMIR Junior Economist Workshop on Migration Research at Ifo Institute for Economic Research in Munich. The views expressed in this paper are those of the author and do not necessarily reflect those of the International Monetary Fund or the World Bank.

${ }^{\dagger}$ The World Bank Group, 1818 H St NW, Washington, DC 20433 (email: rcmbeyer@worldbank.org).
} 


\section{INTRODUCTION}

After earlier waves in the 1960s and 1990s, immigration to Germany has been on the rise again since the Global Financial Crisis and skyrocketed in 2015 when over two million people moved to Germany. Due to the EUTurkey refugee deal immigration decreased considerably last year but whether the decline is permanent still has to be seen. Besides addressing pressing humanitarian concerns, immigration could potentially counterbalance the expected gradual decline of the working age population as a result of aging. For these benefits to labor supply to materialize, as well as to favor social integration and maximize the contribution to the public finances, the integration of immigrants into the labor market is crucial.

Against this background, this study explores the labor market performance of immigrants in Germany in the past using micro-data from a large household survey, the German Socio-Economic Panel. It estimates Mincer-type models of the determinants of wages, unemployment, and labor force participation, contrasting the outcomes of natives and immigrants. It uses recent data containing an expanded immigrant sample and methods that are standard but adequate for such an analysis. The paper is partly synoptic and provides a comprehensive overview of the labor market performance of immigrants by updating and bringing together existing knowledge. In addition, it contributes to that literature by highlighting a new factor as an important driver of wage differences between natives and immigrants: the difficulty that immigrants experience to secure jobs that pay higher wages because due to a higher "occupational autonomy". Tasks are increasingly used to explain patterns of wages and employment. For example, Spitz-Oener (2006), Dustmann et al. (2009), Antoncyk et al. (2009), Black and SpitzOener (2020) and Gathmann and Schöneberg (2010) all use task measures to study the interaction of wages with technological changes or changing task inputs. ${ }^{1}$ I use a related measure of "occupational autonomy" to explain the immigrant wage gap. Including this variable in the analysis also provides new insights on the issue of immigrants' skill downgrading in Germany.

I document that employed immigrants initially earn 20 percent less than employed natives with otherwise identical characteristics. For the more recent cohorts wages initially catch-up by a little over one percentage point per year, but the process slows down over time and it takes more than 25 years for their wages to fully converge. The wage gap of earlier cohorts decreases at a much slower pace and even after 30 years is still substantial. Immigrants without German writing skills or a German degree have a wage gap as high as 30 percent initially. Good German writing skills close the gap by 10 percentage points and a German degree by another 5 percentage points. The latter finding shows that the benefit of experience in Germany is larger for those who arrive when

\footnotetext{
${ }^{1}$ See Autor (2013) for a great overview of this literature.
} 
they are still in education. The gap for immigrants born in advanced countries is a third of that of other immigrants. Half of the immigrant-native wage gap can be explained by a lower level of job autonomy of immigrants compared to natives (given other individual characteristics).

Turning to unemployment, the probability of being unemployed is initially 7 percentage points higher for recently arrived immigrants than for natives with the same characteristics. While the gap narrows over time, in the longrun the probability remains 3 percentage points higher. Again, German language skills and a German degree help closing the gap and immigrants from advanced countries perform better than other immigrants. While the participation rate of immigrants is also initially lower - with the expected effects of the immigrants' characteristics - the participation rate has fully converged after 20 years spent in Germany.

The rest of the paper is structured as follows. Section 2 provides a short overview of immigration to Germany. Section 3 briefly reviews related literature and Section 4 presents the data. In Section 5 I use some simple descriptive statistics to sketch out one of the main findings that is later established more formally. The empirical model for the analysis is described in the short Section 6. The next three sections report the results. Section 7 is on wages, Section 8 on occupational autonomy, and Section 9 on unemployment and participation. Robustness checks are reported in Section 10 and Section 11 concludes.

\section{IMMIGRATION TO GERMANY - A SHORT OVERVIEW}

In Germany a very high fraction of the population is foreign-born. In 2013, over 10 million foreign-born persons lived in Germany, about 13 percent of the population. This share was very similar to the one in the U.S. and in the U.K., but smaller than in Sweden or Canada. However, 15 million Germans have had at least one foreign-born parent (Gathmann and others, 2014), which leads to a fraction of persons with a migration background - defined as having at least one foreign-born parent - as high as in Canada.

In the 1950s total movements were very low and net immigration was basically zero. Rapid economic growth resulted in an acute shortage of labor by the middle of the decade, which led to recruitment agreements between Germany and Turkey and some Southern European countries beginning in 1955. Starting in 1960, Germany experienced the intended net immigration. The immigrants during this period originally came as "guest workers" rather than to settle permanently but many of them stayed in Germany. In 1973, when the economy was hit by the first oil crisis, a recruitment ban on guest workers was imposed with exceptions only for highly skilled and seasonal workers. As a result, net inflows fluctuated around zero until the late eighties. The second large migration wave was triggered by the fall of the iron curtain and the consequent large inflows in particular of ethnic Germans from Eastern Europe. In the early 1990s Germany experienced positive annual net immigration of 
more than 750,000 individuals. The inflows were thus slightly higher than the highest inflows during the first wave. In the second half of the 1990s, net immigration decreased slowly but steadily and after a small and temporary increase in the early 2000s turned negative right before the global financial crisis erupted in 2008. Since then, inflows have been increasing much faster than outflows and net immigration in 2014 was above 550,000 , i.e. 0.6 percent of the population. While this was already a high number, it was well below the peak reached in the early 1990s. With 1.1 million, net immigration surged to record numbers in 2015. Last year, immigration decreased considerably due to the EU-Turkey refugee deal. Whether the decline is permanent, however, is highly uncertain.

Up until 2013, the post-crisis surge in net immigration to Germany consisted mainly of movements within the EU, which surpassed a quarter of a million people in 2012. In 2014, net immigration from the EU surpassed 300,000. Net immigration from EU countries started to increase significantly in 2010 and 2011, both due to the financial crisis and due to lifting restrictions on immigration from countries that entered the EU in 2004 in May 2011. Inflows from Bulgaria and Romania, which joined the EU in 2007, also picked up, though restrictions on immigration from these countries to Germany were fully lifted only from 2014 onwards. While immigration from Southern Europe increased sharply, likely reflecting deep recessions and rising unemployment, total movements were not very large. However, even if most of the immigrants after the financial crisis came from Eastern Europe, their inflows have to a large extent resulted from the economic conditions in Southern Europe: with job opportunities vanishing in Southern Europe, perspective immigrants may have chosen to go to Germany instead. By controlling for the attractiveness of alternative destinations, Bertoli et al. (2013) argue that nearly 80 percent of the surge in immigration to Germany after the Global Financial Crisis resulted from diversion effects. Since 2010, Germany is also experiencing positive and rising net immigration from outside the EU, reaching 150,000 in 2013 and 250,000 in 2014 and 750,000 in 2015. The latest increase mainly reflects an increase in arriving asylum applicants (Germany received over 30 percent of all EU applications).

Summarizing, the new wave of immigration under way in Germany is rapidly changing: while it initially reflected mainly immigrants from new EU accession countries and, to a smaller extent, Southern Europe, the wave now consists to a large extent of asylum seekers from outside of the EU. From 2010 to 2013, immigrants from the EU accounted for roughly two thirds of total net immigration in each year. In 2014, net immigration from within the EU and from outside of the EU was nearly equally strong and in 2015 net immigration from outside of the EU was much higher than from within. As will be shown below, the characteristics of immigrants are very important factors in their labor market integration experience. 


\section{LITERATURE REVIEW}

There is a very large literature on the labor market performance of immigrants, which this paper cannot comprehensively survey. ${ }^{2}$ However, some findings particularly important for my analysis are described below.

Since Chiswick (1978), it is known that in the U.S. immigrants start with much lower wages than natives with similar characteristics and then slowly catch up. The initial wage penalty is often interpreted as devaluation of human capital obtained in another country (e.g. Chiswick and Miller, 2009). Over time, immigrants' wages converge to those of natives as immigrants invest in human capital and find jobs with higher earnings, a better fit, or in higher-paying industries and occupations. In addition, employers over time learn about the true productivity of the immigrants. There is some evidence that immigrants even overtake natives after 10 to 15 years in the U.S. and Canada (Chiwick, 1978; Meng, 1987). The reason could be that immigrants are a self-selected group with potentially higher levels of labor market ability and motivation. Borjas (1999) criticizes the way these studies measure assimilation, however, as the identified wage convergence could result from lower productivity of more recent immigrants as well.

Adsera and Chiswick (2007) and Dustmann and Frattini (2011) document strong earning gaps in European countries. In line, Algan et al. (2010) discuss wage gaps in France, Germany, and the UK and show that they can be substantial but differ for different immigrant groups. In Germany, for example, the gap used to be largest for immigrants from Greece and Turkey. In contrast to the US, there is no clear evidence of wage convergence in Germany. While some papers find a catching-up process (Constant and Massey, 2005; Gundel and Peters, 2007, Büchel and Frick, 2004, Lehmer and Ludsteck 2011, 2014), others do not (Pischke, 1992, Dustmann 1993 , Schmidt, 1997; Bauer and others 2005). Fertig and Schurer (2007) account for time-invariant individual unobserved heterogeneity and panel attrition and find full convergence for some but not all immigrant cohorts. Gathmann and Keller (2014) find a positive effect of naturalization on assimilation especially for women and more recent immigrants.

Another crucial discussion is related to the immigrants' skill downgrading in the receiving country. This can either mean that immigrants in the destination country do jobs that require less qualification than the job they did in the home country (Akresh, 2008) or that immigrants - given other characteristics and, in particular, education levels - perform worse than natives in the destination country. Using the latter definition, Dustmann et al. (2013)

\footnotetext{
${ }^{2}$ A good and more comprehensives overview of the literature is offered by de la Rica et al. (2013).
} 
show that immigrants in the U.K., conditional on education, tend to work in jobs with a lower socio-economic classification than natives. Dustmann and Frattini (2011) show that immigrants in most European countries work in occupations that require less skills than the immigrants actually have. Basilio et al. (2014) document that education and experience accumulated in the immigrants' home countries deliver lower returns than human capital obtained in Germany and argue that these differences are crucial for explaining the immigrants' wage gap.

Many papers have analyzed the effect of language skills on the earnings of immigrants. Bleakley and Chin (2004) show that English proficiency has a positive effect in the U.S. and Dustmann and van Soest $(2001,2002)$, Aldashev, Gernandt, and Thomsen (2009) and Zibrowius (2012) show that German language skills reduce the wage penalty of immigrants in Germany.

Regarding unemployment, Chiswick, Cohen, and Sachs (1997) report an initially higher unemployment rate of immigrants in the U.S. but a fast assimilation. Early work for Germany looks at guest workers and ethnic German refugees after World War II. It shows that in the eighties foreigners generally faced the same risk of unemployment than natives (Mühlhausen and Zimmermann, 1994) but that there were differences between migrants from different origin countries (Bauer and Zimmermann, 1997). Kogan (2005), for a later period, shows that immigrants in Germany are more likely to be unemployed and that the higher risk of unemployment is only partially related to their lower human capital but results also from their unfavorable labor market allocation. Uhlendorff and Zimmermann (2014) argue that the reason for often higher unemployment rates of immigrants in Germany compared to natives are caused by longer unemployment spells and not from shorter employment spells. In addition, they document strong heterogeneity for immigrants from different origin countries and identify those from Turkey as having the highest probability of unemployment.

Regarding employment, Algan et al. (2010) show that in France, Germany and the U.K. immigrants have lower employment rates than natives and that the probability to be in employment depends on the country of origin. They document a convergence of employment rates for second-generation immigrants from some but not all origin countries. Dustmann and Frattini (2011) discuss employment gaps between immigrants and natives for 15 Western European countries and show that it can be up to 15 percentage points.

The contribution of this paper to the literature is twofold. First, it updates many of the results mentioned above and provides a comprehensive overview of the labor market performance of immigrants in Germany. To do so, it builds strongly on previous studies and uses recent data with an extended immigrant sample that has, to the best 
of my knowledge, not yet been used to study the labor market performance of immigrants. ${ }^{3}$ Second, it includes a variable on occupational autonomy to account for the fact that there is not only a return to skills, but also to tasks. It turns out that the difficulty of immigrants to secure jobs with higher wages due to a higher autonomy is crucial for explaining the wage gap.

\section{DATA}

\subsection{The German Socio-Economic Panel}

The analysis is based on the German Socio-Economic Panel (SOEP) ${ }^{4}$, which is a representative household survey located at the German Institute for Economic Research (DIW) in Berlin. The survey started in 1984 with around 12,000 participants. This number doubled over time and 24,000 individuals were interviewed for the 2013 wave. The panel is organized on a household basis but all participants aged at least 16 years are personally interviewed. It is the largest survey of immigrants in Germany and it oversamples the immigrant population. In 2013, an additional immigrant sample of 5000 persons was added. The new immigrants are sampled using the 2011 census to take into account compositional changes since 1995. This dataset is most suitable for the analysis as it has a lot of information absent in other data sources often used to study the German labor market empirically. In particular, it has information on the place of birth and the immigrant's year of arrival, whereas social security data provided by the Federal Institute for Employment Research (IAB), which is of high quality and often used, only has information on the nationality and no information when immigrants arrived. The drawback of using the SOEP is that, even though the dataset is large, cell sizes can become small.

\subsection{The Dependent and Control Variables}

I include the following variables that are either taken directly from the survey or constructed from other variables included therein:

Labor Force Status. Each person is either working, or unemployed, or not part of the labor force.

Hourly Real Wages. I transform both monthly gross and net nominal wages into hourly gross and real wages using the actual working hours per week (similar to Knabe and Schoeb, 2009; Falck et al., 2013; Brenke and

\footnotetext{
${ }^{3}$ Battisti and Felbermayr (2015) use the data to compare the fraction of immigrants who in 2013 earned less the minimum wage which was introduced later. They restrict their analysis to descriptive statistics and do not discuss the immigrant wage gap.

${ }^{4}$ See Wagner et al. (2007) for more details on the dataset.
} 
Müller, 2013; and Battisti and Felbermayr, 2015). In the baseline, I use the wages before taxes (gross wages) but net wages are analyzed as well. ${ }^{5}$

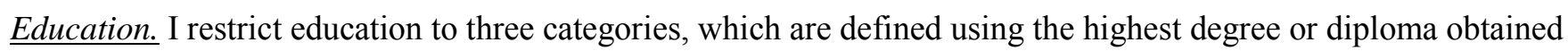
according to the ISCED-1997 classification. I define ISCED-1 and ISCED-2 as "low", ISCED-3 and ISCED-4 as “medium", and ISCED-5 and ISCED-6 as "high" education. Low education will always be the benchmark.

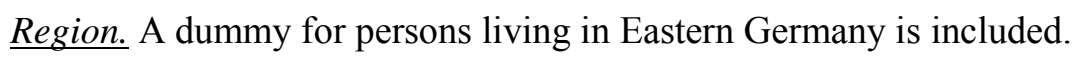

Working and Unemployment Experience. I include both the years of full-time work experience and years of unemployment experience.

Years Spent in Firm. This variable measures the time spent with the current employer in years.

Job that Requires High Qualification. This dummy is one when the job requires a degree from a college or university and zero otherwise.

Autonomy Status of the Job. This is a measure specifically designed for the SOEP. It measures the autonomy level of the occupational activity and groups jobs on a scale from 1 (low) to 5 (high) based on task descriptions, level of responsibility, training required, and company size. Unspecialized manual labor is in the "low" category; farm work and production and services that require at least minimal specialization are in the "low-medium" category; jobs that require middle track of secondary school and involve some responsibility as well as self-employed without any employees are in the "medium" category; work that requires college and self-employed work with some employees is in the "medium-high" category; and managers, freelance academics and self-employed with many employees are in the "high" category. The autonomy level is strongly correlated with the wage; a one-level step in the job autonomy scale is associated with an average wage increase of 20 percent. For more details regarding this variable and how it compares to other international job classifications and rankings see HoffmeyerZlotnik and Geis (2003).

Industry. I include ten categories for the industry in which a person is working. The categories are Agriculture, Energy, Mining, Manufacturing, Construction, Trade, Transport, Bank and Insurances, Services, and Others.

Being Trained for Job. Survey participants are asked whether they are working in the occupation they have been trained for. I include three possible values: “yes", "no", and "no training”. Not working in an occupation one is trained for is the omitted category.

\footnotetext{
${ }^{5}$ The typical caveats are in place: as respondents report their earnings on a monthly basis but working hours on a weekly basis, measurement errors for calculated hourly wages may arise especially at the bottom of the wage distribution (Müller, 2009). Moreover, there are problems of missing information or incorrect values for self-reported income (Falck and others, 2013).
} 
Immigrant. This dummy is zero for all persons born in Germany and one for those not born in Germany. Hence immigrants are defined by foreign birth.

In addition, I include the Age, the Gender, whether a person is Married, the Survey Year, and for those working whether they do a Full-Time Job and in which Industry they are working. Finally, I add some variables specific to the immigrants. These variables are:

Years since Immigration. This is calculated as the difference between the survey year and the year of arrival in Germany. This variable is a proxy for the experience gained in the country and opportunities for social integration. I also use the squared number of years in order to account for possibly non-linear effects.

German Degree. From the information in the survey, I can construct a dichotomous variable that is one when the immigrant obtained a degree in Germany, and zero otherwise.

Born in Advanced Country. The SOEP contains information on the country of birth of the immigrant. I group countries in advanced and non-advanced based on the IMF classification. Immigrants from advanced countries may have better alternative options if they do not find good jobs in Germany relative to immigrants from other countries.

German Writing Skills. I use information in the survey to construct a dummy that is one if an immigrant has good or very good German writing skills. As this variable has many missing observations, a third category for missing values is included.

\subsection{Sample, Data Modifications, and Descriptive Statistics}

The original sample uses all 35 vintages from 1984 to 2013 and has 502,000 observations ${ }^{6}$. For the empirical analysis, the sample is restricted to persons between 16 and 70 years old, resulting in a loss of 70,000 observations. Observations are only lost for those years, in which the person is not in the considered age group. I also drop observations with unknown place of birth $(2,000)$, immigrant with unknown year of arrival in Germany $(3,000)$, those for whom it cannot be identified where they obtained their degree $(10,000)$, those who are in education, have already retired, or are in maternity leave $(54,000)$, those with unknown education $(3,000)$ and those for which the individual sample weight is zero (7,000). This leaves 350,000 observations. For the analysis of the wage performance, I also drop persons who are not working $(79,000)$, for whom the required job training is unknown (7,000), who worked less than 10 hours a month, who did not report positive wages and for whom real wages cannot be computed ${ }^{7}$ (together 28,000 ), those for whom the time spent in the firm and the occupational

\footnotetext{
${ }^{6}$ Socio-Economic Panel (SOEP), data for years 1984-2013, version 30, SOEP, 2015, doi: 10.5684/soep.v30.

${ }^{7}$ This refers to East German wages in 1990.
} 
autonomy are unknown (together 1,000) and those with an occupational autonomy below one $(12,000) .{ }^{8}$ This leaves 224,000 observations. I transform monthly nominal gross earnings into hourly real wages and replace wages below the 5 percent and above the 99 percent percentile with the respective value of the percentile in that year. For experience, training, industry, and language proficiency I also add dummies for missing values. In 2013, natives were on average 44.9 years old and immigrants with 43.7 years a little younger. The fraction of women was 50 percent and 51 percent respectively. More natives had medium and high education than immigrants. However, of those who migrated after 2007, the fraction of highly educated was considerably higher than in the native population. The fraction of unemployed was 6 percent among the natives but 10 percent among the immigrants, while the participation rate was only slightly lower among the immigrants. Three out of four immigrants were able to speak good or very good German and nearly two thirds had good or very good German writing skills. A little over a third of the immigrants obtained an educational degree in Germany and on average they had been in Germany already for 22.5 years. Looking closer at the working population shows that while the working experience is similar, immigrants spent on average more time unemployed, namely 1.1 years versus 0.6 years. Immigrants were less likely than natives to have a job for which they were trained (41 percent versus 59 percent) and less highly skilled immigrant than natives had a job that required high education (14 percent versus 22 percent). Finally, the occupational autonomy of immigrants was also lower than that of natives ( 2.2 versus 2.8). ${ }^{9}$

Table 1 Raw Wage Gaps in 2013

\begin{tabular}{|c|c|c|c|c|c|c|c|c|}
\hline \multicolumn{3}{|c|}{ Total Population } & \multicolumn{3}{|c|}{ Women } & \multicolumn{3}{|c|}{ Men } \\
\hline \multicolumn{2}{|c|}{ Hourly Real Wage } & \multirow[t]{2}{*}{ Gap } & \multicolumn{2}{|c|}{ Hourly Real Wage } & \multirow[t]{2}{*}{ Gap } & \multicolumn{2}{|c|}{ Hourly Real Wage } & \multirow[t]{2}{*}{ Gap } \\
\hline Natives & Immigrants & & Natives & Immigrants & & Natives & Immigrants & \\
\hline $\begin{array}{c}15.0 \\
(0.10)\end{array}$ & $\begin{array}{c}12.7 \\
(0.24)\end{array}$ & $15.3 \%$ & $\begin{array}{c}13.4 \\
(0.15)\end{array}$ & $\begin{array}{c}11.0 \\
(0.34)\end{array}$ & $17.9 \%$ & $\begin{array}{c}16.5 \\
(0.20)\end{array}$ & $\begin{array}{c}14.3 \\
(0.18)\end{array}$ & $13.3 \%$ \\
\hline
\end{tabular}

Note: Standard errors are in parenthesis.

Source: SOEP 2013, own calculations

Table 1 shows the raw wage gaps of natives and immigrants separately for the total population, women and men. On average a working native in 2013 earned 15.0 Euros per hour and an immigrant earned on average 12.7 Euros per hour. The unconditional wage gap is hence 15.3 percent. It is much larger for women than for men. These raw

\footnotetext{
${ }^{8}$ Category 0 is for apprentice, interns and unpaid trainees.

${ }^{9}$ Tables showing the minimum, median, and average of all variables for the full sample and the working population are available upon request.
} 
wage gaps do not take into account the different characteristics of natives and immigrants. I just discussed some of them that obviously influence wages, with the most obvious one being education.

\section{CONDITIONAL WAGE GAPS AND DOWNGRADING OF IMMIGRANT SKILLS - A FIRST GLANCE}

In this section I use the 2013 survey and some simple descriptive statistics in order to point out some of the most striking results established more formally in the next section. The left panel of Figure 1 presents the wage gap of natives and immigrants (in percent) by level of education according to the ISCED classification, where the last category combines ISCED-5 and ISCED- $6 .{ }^{10}$ The filled bars show statistically significant gaps. ${ }^{11}$ The figure shows that conditional on education natives earn more than immigrants. The gap for very low education is not significant because there are very few natives with such a low education.

Figure 1 Conditional Immigrant-Native Wage Gaps in 2013
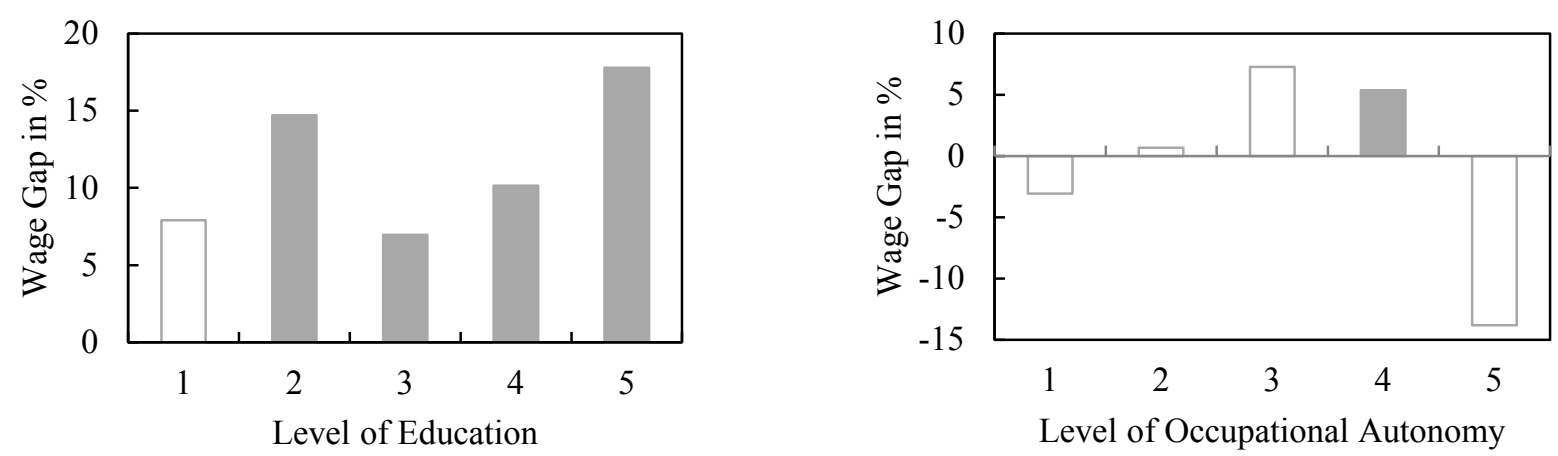

Note: Filled bars are statistically significant and the $1 \%$ level.

Source: SOEP 2013, own calculations.

Interestingly, in contrast to education, the wage gaps vanish when conditioning on occupational autonomy, as can be seen in the right panel of Figure 1. Not only are the wage gaps insignificant, but for two out of the five categories immigrants even earn more than natives and for one category the gap is basically zero. There is a significant positive gap only for the medium-high autonomy category, which could be related to the particular German apprenticeship system. The comparison of the two panels suggests, first, that given the kind of job immigrants and natives do there is no more wage gap and, secondly, that immigrants with the same education do not have jobs of the same occupational autonomy as natives. The pattern can be explained by skill downgrading of immigrants.

\footnotetext{
${ }^{10}$ A table showing the actual wages of natives and immigrants as well as the frequency of each education and autonomy level in each subgroup is available upon request.

${ }^{11}$ The gap for education 2 and 5 are significant at the 1 percent level, for 4 at the 5 percent level and for 3 at the 10 percent level. The gap for occupational autonomy 4 is significant at the 5 percent level.
} 
Figure 2 Downgrading of Immigrants’ Education in 2013

a) Low Education

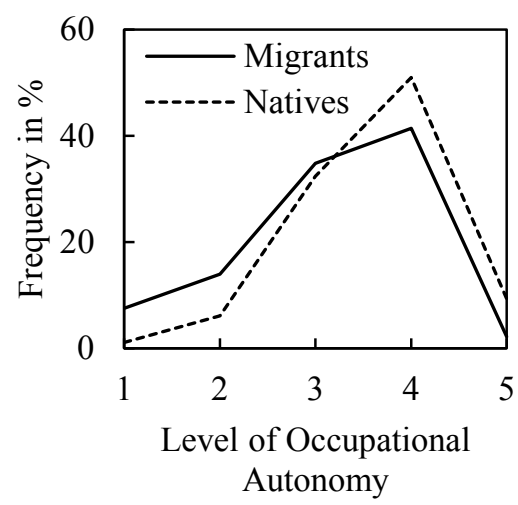

b) Medium Education

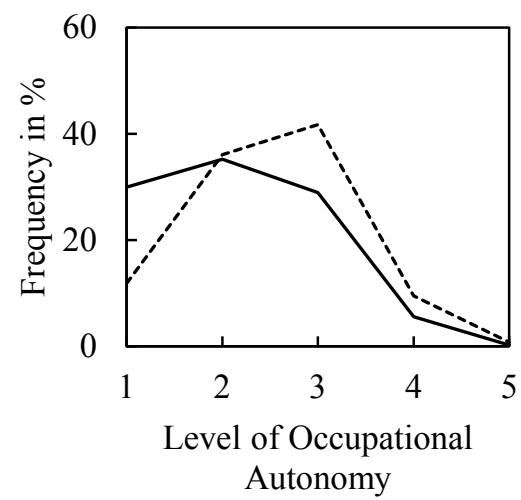

c) High Education

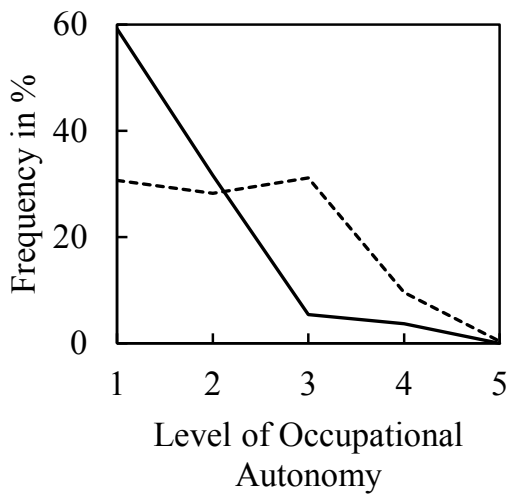

Note: Lines show the frequency of occupational autonomy separately for immigrants and natives in $\%$.

Source: SOEP 2013, own calculations.

Figure 2 visualizes the skill downgrading of immigrants. It reduces the five education levels to three as described in the data section. It shows for each of the categories the frequency of the different levels of occupational autonomy separately for natives and immigrants. Note that the natives' curve is shifted to the right in all panels. That means that for all three categories there is a higher fraction of natives with medium-high and high autonomy and a lower fraction with low and medium-low autonomy. Hence immigrants with the same education do not manage to perform as well on the autonomy scale as natives. Immigrants who arrived before 1990 are less disadvantaged than others but significant differences remain for this group. Those who arrived after 2007 perform particularly badly: in this group, one out of four highly educated immigrant has a job with low or low-medium autonomy, while the same is true for only one out of 14 natives.

The level of occupational autonomy is strongly correlated with wages and going up one level increases the wage on average by 20 percent. Skill downgrading of immigrants, therefore, has the potential to explain some of the wage gap observed before. Clearly, the skill downgrading does not necessarily result from discriminatory preferences, as it may reflect other characteristics of immigrants that have not been controlled for. Immigrants without language skills, for example, cannot be expected to take over responsibility and management duties to the same extent as a native. Another factor could be a different quality of the educational degrees obtained in Germany and abroad. These are variables that I will consider in the formal analysis in the next section. 


\section{EMPIRICAL PROCEDURE}

In the following I estimate Mincer-type wage equations, autonomy equations, as well as unemployment and participation equations. In general, all estimated models have the following structure:

$$
x_{i t}=\beta_{1}^{\prime} E_{i t}+\beta_{2}^{\prime} M_{i t}+\beta_{3}^{\prime} C_{i t}+\varepsilon_{i t},
$$

with $x_{i t}$ being either the natural logarithm of the hourly real wage, the autonomy level, or a dummy for being unemployed or part of the labor force; $E_{i t}$ being a vector of all explanatory variables common to immigrants and natives; $M_{i t}$ containing the variables specific to the immigrants, which are all estimated as interaction terms; $C_{i t}$ comprising the controls, whose coefficients are not reported; and $\varepsilon_{i t}$ is an error term. ${ }^{12}$ Depending on the specification, I estimate pooled OLS, logit or ordered logit models. As persons are in the survey for many consecutive years, I cluster standard errors on the individual level in order to account for individual error correlation. All models are estimated using the individual sample weights. In order to validate the wage convergence over time, I later estimate a specification with personal fixed effects.

I provide robustness checks of the baseline results in Section 10: (1) I estimate the models without using sample weights, (2) I estimate probit instead of logit models, (3) I use a Heckman selectivity correction, and (4) I employ a random-group variance estimator.

\section{MINCER-TYPE WAGE EQUATIONS}

In all of the following specifications I use the natural logarithm of the hourly real wage before taxes as the dependent variable. Since estimation is done in natural logarithms, coefficients can be interpreted as marginal effects in percent. As controls in all of the following wage equations I use the region, whether a person is married, works full time, the age, the number of years in the firm, as well as year and industry dummies. The models are estimated with all 224,000 observations. ${ }^{13}$

\footnotetext{
${ }^{12}$ On the one hand, including dummies is important, because they explain differences between immigrants and natives. On the other hand, they may themselves be governed by discriminatory preferences and hence hide some of the differences. Two typical caveats of such an analysis are, first, that some variables like language skills both affect and are affected by the labor market outcomes and, second, that different immigrant groups may have self-selected on basis of included variables like industry or education. As long as these effects are not too important, the potential bias is small. Nevertheless, they make a causal interpretation of the results difficult.

${ }^{13}$ Cross-correlations are available upon request.
} 
Table 2 Mincer-type Wage Regression Output

\begin{tabular}{|c|c|c|c|c|c|c|c|c|c|c|}
\hline & $(1)$ & $(2)$ & (3) & (4) & $(5)$ & (6) & (7) & $(8)$ & (9) & $(10)$ \\
\hline Experience & $\begin{array}{l}0.019 * * * \\
(0.00089)\end{array}$ & $\begin{array}{l}0.019 * * * \\
(0.00089)\end{array}$ & $\begin{array}{l}0.019 * * * \\
(0.00089)\end{array}$ & $\begin{array}{l}0.019 * * * \\
(0.00089)\end{array}$ & $\begin{array}{l}0.019 * * * \\
(0.00089)\end{array}$ & $\begin{array}{l}0.019 * * * \\
(0.00088)\end{array}$ & $\begin{array}{l}0.019 * * * \\
(0.00087)\end{array}$ & $\begin{array}{l}0.018 * * * \\
(0.00082)\end{array}$ & $\begin{array}{l}0.018 * * * \\
(0.00082)\end{array}$ & $\begin{array}{l}0.019 * * * \\
(0.00081)\end{array}$ \\
\hline Experience Squared & $\begin{array}{c}-0.00044 * * * \\
(0.000019)\end{array}$ & $\begin{array}{c}-0.00043 * * * \\
(0.000019)\end{array}$ & $\begin{array}{c}-0.00044 * * * \\
(0.000019)\end{array}$ & $\begin{array}{c}-0.00044 * * * \\
(0.000019)\end{array}$ & $\begin{array}{c}-0.00044 * * * \\
(0.000019)\end{array}$ & $\begin{array}{c}-0.00044 * * * \\
(0.000019)\end{array}$ & $\begin{array}{c}-0.00044 * * * \\
(0.000018)\end{array}$ & $\begin{array}{c}-0.00041 * * * \\
(0.000017)\end{array}$ & $\begin{array}{c}-0.00040 * * * \\
(0.000017)\end{array}$ & $\begin{array}{c}-0.00041 * * * \\
(0.000017)\end{array}$ \\
\hline Medium Education (ME) & $\begin{array}{l}0.11 * * * \\
(0.0075)\end{array}$ & $\begin{array}{l}0.11 * * * \\
(0.0075)\end{array}$ & $\begin{array}{l}0.11 * * * \\
(0.0075)\end{array}$ & $\begin{array}{l}0.11 * * * \\
(0.0075)\end{array}$ & $\begin{array}{l}0.11 * * * \\
(0.0075)\end{array}$ & $\begin{array}{l}0.073 * * * \\
(0.0076)\end{array}$ & $\begin{array}{l}0.065 * * * \\
(0.0075)\end{array}$ & $\begin{array}{l}0.035 * * * \\
(0.0070)\end{array}$ & $\begin{array}{l}0.041 * * * \\
(0.0079)\end{array}$ & $\begin{array}{l}0.045 * * * \\
(0.0079)\end{array}$ \\
\hline Migrant with ME & & & & & & & & & $\begin{array}{l}-0.025^{*} \\
(0.014)\end{array}$ & $\begin{array}{l}-0.022 \\
(0.014)\end{array}$ \\
\hline Migrant with HE & & & & & & & & & $\begin{array}{c}-0.087^{* * *} \\
(0.022)\end{array}$ & $\begin{array}{c}-0.085^{* * * *} \\
(0.024)\end{array}$ \\
\hline HE Job Match & & & & & & & & & & $\begin{array}{c}0.22 * * * \\
(0.010)\end{array}$ \\
\hline Migrant with HE Job M. & & & & & & & & & & $\begin{array}{l}0.060^{*} \\
(0.033)\end{array}$ \\
\hline Female & $\begin{array}{l}-0.12 * * * \\
(0.0068)\end{array}$ & $\begin{array}{l}-0.12 * * * \\
(0.0068)\end{array}$ & $\begin{array}{l}-0.12 * * * \\
(0.0068)\end{array}$ & $\begin{array}{l}-0.12 * * * \\
(0.0068)\end{array}$ & $\begin{array}{l}-0.12 * * * \\
(0.0068)\end{array}$ & $\begin{array}{l}-0.13 * * * \\
(0.0067)\end{array}$ & $\begin{array}{l}-0.13 * * * \\
(0.0067)\end{array}$ & $\begin{array}{l}-0.12 * * * \\
(0.0062)\end{array}$ & $\begin{array}{l}-0.12 * * * \\
(0.0062)\end{array}$ & $\begin{array}{l}-0.11 * * * \\
(0.0061)\end{array}$ \\
\hline Trained for Job & & & & & & & $\begin{array}{c}0.087 * * * \\
(0.0051)\end{array}$ & $\begin{array}{c}0.028 * * * \\
(0.0049)\end{array}$ & $\begin{array}{l}0.028 * * * \\
(0.0049)\end{array}$ & $\begin{array}{l}0.021 * * * \\
(0.0048)\end{array}$ \\
\hline Autonomy (Job Type) & & & & & & & & $\begin{array}{l}0.13 * * * \\
(0.0030)\end{array}$ & $\begin{array}{l}0.13 * * * \\
(0.0030)\end{array}$ & $\begin{array}{l}0.11 * * * \\
(0.0030)\end{array}$ \\
\hline Migrant & $\begin{array}{c}-0.073 * * * \\
(0.0085)\end{array}$ & $\begin{array}{c}-0.21 * * * \\
(0.028)\end{array}$ & $\begin{array}{c}-0.32 * * * \\
(0.030)\end{array}$ & $\begin{array}{c}-0.33 * * * \\
(0.030)\end{array}$ & $\begin{array}{c}-0.31 * * * \\
(0.031)\end{array}$ & $\begin{array}{c}-0.29 * * * \\
(0.031)\end{array}$ & $\begin{array}{c}-0.27 * * * \\
(0.031)\end{array}$ & $\begin{array}{c}-0.16^{* * *} \\
(0.029)\end{array}$ & $\begin{array}{c}-0.12 * * * \\
(0.031)\end{array}$ & $\begin{array}{c}-0.12 * * * \\
(0.030)\end{array}$ \\
\hline Years in Germany & & $\begin{array}{l}0.011 * * * \\
(0.0027)\end{array}$ & $\begin{array}{l}0.011^{* * *} \\
(0.0026)\end{array}$ & $\begin{array}{l}0.010^{* * * *} \\
(0.0027)\end{array}$ & $\begin{array}{c}0.0094 * * * \\
(0.0027)\end{array}$ & $\begin{array}{c}0.0099 * * * \\
(0.0027)\end{array}$ & $\begin{array}{c}0.0090^{* * * *} \\
(0.0027)\end{array}$ & $\begin{array}{c}0.0074 * * * \\
(0.0024)\end{array}$ & $\begin{array}{c}0.0064 * * * \\
(0.0025)\end{array}$ & $\begin{array}{c}0.0068 * * * \\
(0.0024)\end{array}$ \\
\hline YiG Squared & & $\begin{array}{c}-0.00018^{* * *} \\
(0.000060)\end{array}$ & $\begin{array}{c}-0.00018^{* * *} \\
(0.000059)\end{array}$ & $\begin{array}{c}-0.00020 * * * \\
(0.000060)\end{array}$ & $\begin{array}{c}-0.00019 * * * \\
(0.000061)\end{array}$ & $\begin{array}{c}-0.00019 * * * \\
(0.000060)\end{array}$ & $\begin{array}{c}-0.00018^{* * *} \\
(0.000060)\end{array}$ & $\begin{array}{c}-0.00015^{* * *} \\
(0.000054)\end{array}$ & $\begin{array}{c}-0.00013 * * \\
(0.000054)\end{array}$ & $\begin{array}{c}-0.00014 * * * \\
(0.000053)\end{array}$ \\
\hline Good German Writing & & & $\begin{array}{c}0.10^{* * *} \\
(0.020)\end{array}$ & $\begin{array}{c}0.11 * * * \\
(0.020)\end{array}$ & $\begin{array}{c}0.10^{* * *} \\
(0.020)\end{array}$ & $\begin{array}{c}0.089 * * * \\
(0.020)\end{array}$ & $\begin{array}{c}0.085 * * * \\
(0.020)\end{array}$ & $\begin{array}{c}0.052 * * * \\
(0.019)\end{array}$ & $\begin{array}{c}0.064 * * * \\
(0.019)\end{array}$ & $\begin{array}{c}0.051 * * * \\
(0.018)\end{array}$ \\
\hline German Degree & & & $\begin{array}{c}0.054 * * * \\
(0.014)\end{array}$ & $\begin{array}{c}0.058 * * * \\
(0.014)\end{array}$ & $\begin{array}{c}0.057 * * * \\
(0.014)\end{array}$ & $\begin{array}{c}0.044 * * * \\
(0.014)\end{array}$ & $\begin{array}{c}0.040 * * * \\
(0.014)\end{array}$ & $\begin{array}{c}0.00093 \\
(0.013)\end{array}$ & $\begin{array}{l}0.0057 \\
(0.013)\end{array}$ & $\begin{array}{l}0.0060 \\
(0.013)\end{array}$ \\
\hline Advanced Country & & & & $\begin{array}{c}0.11 * * * \\
(0.018)\end{array}$ & $\begin{array}{c}0.11 * * * \\
(0.018)\end{array}$ & $\begin{array}{c}0.096 * * * \\
(0.018)\end{array}$ & $\begin{array}{c}0.094 * * * \\
(0.017)\end{array}$ & $\begin{array}{c}0.063 * * * \\
(0.015)\end{array}$ & $\begin{array}{c}0.065^{* * *} \\
(0.015)\end{array}$ & $\begin{array}{c}0.052 * * * \\
(0.015)\end{array}$ \\
\hline Migrated after 2007 & & & & & $\begin{array}{c}-0.17 * * * \\
(0.058)\end{array}$ & $\begin{array}{c}-0.18 * * * \\
(0.058)\end{array}$ & $\begin{array}{c}-0.17 * * * \\
(0.056)\end{array}$ & $\begin{array}{c}-0.18 * * * \\
(0.055)\end{array}$ & $\begin{array}{c}-0.17 * * * \\
(0.055)\end{array}$ & $\begin{array}{c}-0.17 * * * \\
(0.057)\end{array}$ \\
\hline Observations & 224,272 & 224,272 & 224,272 & 224,272 & 224,272 & 224,272 & 224,272 & 224,272 & 224,272 & 224,272 \\
\hline R-squared & 0.336 & 0.336 & 0.337 & 0.338 & 0.338 & 0.348 & 0.354 & 0.394 & 0.394 & 0.407 \\
\hline
\end{tabular}

Robust standard errors in parentheses

$* * * \mathrm{p}<0.01, * * \mathrm{p}<0.05, * \mathrm{p}<0.1$

As controls I include the region, whether the person is married, works full time, the age and the number of years in the firm, as well as year and industry dummies.

Source: SOEP 1984-2013, own calculations. 


\subsection{Baseline}

First, I only include the years of experience, the years of experience squared in order to account for nonlinear effects, and dummies for medium education, high education as well as for being an immigrant. Results are presented in the first column of Table 2. As expected, wages increase with experience; one additional year raises wages by close to 2 percent at the beginning, but with increasing experience the benefit from additional years becomes smaller and after 20 years the additional benefit is basically zero. Persons with medium education earn 11 percent more than those with low education and those with high education earn 40 percent more. The female wage gap is 12 percent. This regression tells us the wage gap of natives and immigrants conditional on experience and education (and the controls). Remember that the raw wage gap was 15.3 percent and note that being an immigrant now reduces the wage by 7.3 percent. Hence roughly half of the gap observed before can be explained by the few characteristics included in the first specification. The R-squared is with 34 percent high for such a regression.

\subsection{Differentiating among Immigrants}

Next I differentiate among the immigrants, who are of course a very heterogeneous group. The number of years spent in Germany, for example, varies from zero to 60 years. And, as mentioned before, roughly two-thirds of the immigrants have good or very good German writing skills, but the others do not. Other differences include the country of origin and whether immigrants come as students and obtain a German degree, or not.

\subsubsection{Evidence for Assimilation}

Assimilation is traditionally measured by including the years since arrival in Germany as a proxy for the experience acquired in Germany and a squared term as well in order to account for non-linear effects (Chiswick, 1978). Initially, I follow this approach that uses only cross-sectional information. ${ }^{14}$ The second column in Table 2 shows the regression output and Figure 3 plots the assimilation path in the left panel. Immigrants arriving in Germany face an initial wage gap of 21 percent and catch-up by roughly 1 percentage point every year. However, with more years spent in Germany wage convergence slows down and even after 25 years the gap is still around 5 percentage points.

\footnotetext{
${ }^{14} \mathrm{I}$ also added a third-order polynomial but the respective coefficient is insignificant.
} 
Figure 3 Immigrant Wage Assimilation

Immigrant Wage Gap over Time

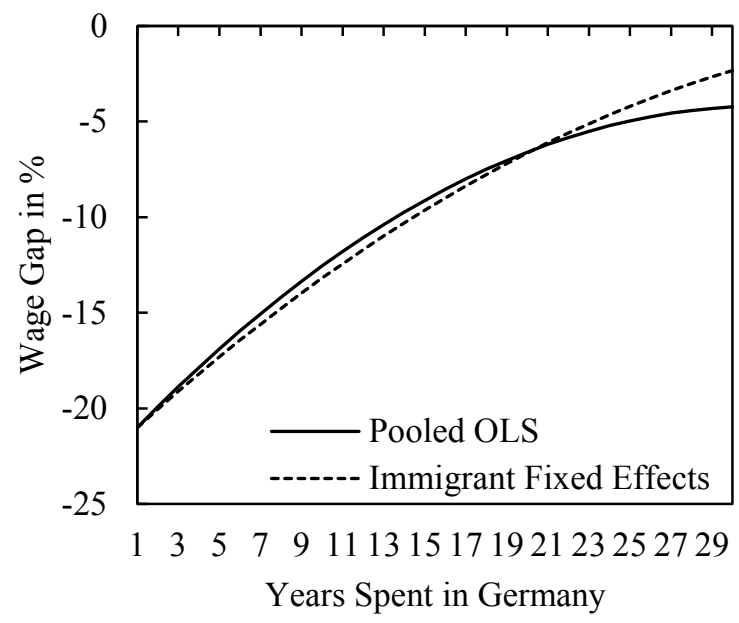

Immigrant Wage Gap for Different Cohorts

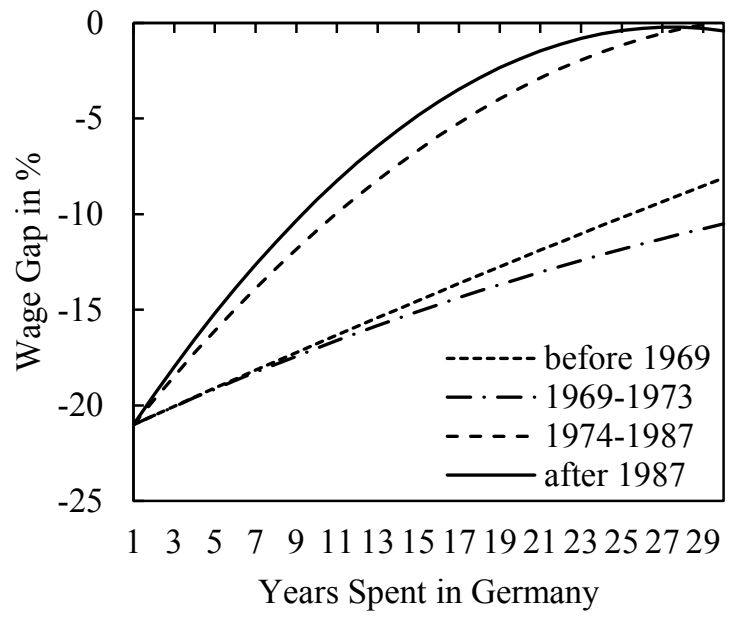

Note: The right panel is based on personal fixed-effects regressions with interaction terms of years spent in Germany and the period of arrival.

Source: SOEP 1984-2013, own calculations.

As mentioned before, Borjas (1999) criticizes this approach as it could capture a secular decline in the productivity of later immigrant cohorts. In addition, panel attrition may be a concern if leaving the sample is linked to labor market performance. I therefore make use of the longitudinal nature of the SOEP data to validate the cross-sectional estimation. To allow for a strong test of the assimilation result, I now restrict the sample to the immigrants and estimate the same model using personal fixed effects. ${ }^{15}$ Restricting the sample allows for immigrant-specific effects of all explanatory variables and hence maximal flexibility. Using personal fixed effects exploits the longitudinal nature of the data and accounts for unobserved heterogeneity. Moreover, a possible bias from attrition is eliminated as long as the systemic link between staying in the sample and the labor market performance is constant over time. ${ }^{16}$ Of course, when including personal fixed effects the effect of variables that do not change over time, like gender, cannot be estimated. Table A1 in the Appendix shows the estimation results in the first column. I can compare the assimilation processes from the two very distinct estimations by replacing the coefficients on the years spent in Germany. The alternative assimilation is also shown in the left panel of Figure 3 . The results are very similar to the cross-sectional estimations with noticeable differences only

\footnotetext{
${ }^{15}$ I agree with Fertig and Bauer (2007) that using fixed effects is more appropriate than using random effects in order to truly control for unobserved heterogeneity.

${ }^{16}$ While systematic links seem present, the bias due to attrition is usually rather small (Hausman and Wise, 1979;

Becketti et al., 1988; Lillard and Panis, 1998; Behr et al., 2003; Fertig and Schurer, 1997).
} 
after 20 years. With the fixed effects estimation the wage convergence does not slow down as much so that the gap after 30 years is $2.2 \%$ instead of $4.2 \%$.

Next, I differentiate between different cohorts to acknowledge the finding of Fertig and Schurer (2007) that the wages of only some but not all cohorts converge. To do so, I interact the years spent in Germany (and the squared ones) with a dummy for four different categories. The cohorts are the following: (1) those who arrived before 1969 to capture the first wave of guest workers, (2) those who arrived between 1969 and 1973 to capture the second wave of guest workers, ${ }^{17}$ (3) those who arrived between 1974 and 1987 mainly due to family re-unification, and (4) all those arriving later including many ethnic German immigrants and more recently many EU migrants. The assimilation paths are shown in the right panel of Figure 3 and confirm Fertig and Schurer (2007). ${ }^{18}$ For guest workers the assimilation is not statistically significant and moreover they have a large gap even 30 years after arrival. For both later cohorts, however, assimilation is significant and wages have fully converged after 25 years.

\subsubsection{German Language Skills and German Degrees}

I now include interaction terms for immigrants with good or very good German writing skills and for those with a German degree. ${ }^{19}$ That way it is possible to test whether there is an additional benefit from schooling in Germany beyond better language skills.

The third column in Table 2 shows the results. The wage gap increases to over 30 percent for those without any beneficial characteristics. Good German writing skills close the gap by 10.0 percentage points and having a German degree decreases the gap by an additional 5.4 percentage points. ${ }^{20}$ It is not surprising that German writing skills improve the immigrant's productivity and therefore also the wage. The additional effect from a German degree could result either from a superior quality of education in Germany compared to that in immigrants' origin countries or from specific skills or information necessary to perform well on the German labor market that are transferred only in German schools. In line with this result, Basilio et al. (2014) show that immigrants receive a lower return on education obtained in the home country compared to education obtained in Germany.

\footnotetext{
${ }^{17}$ This distinction follows Fertig and Schurer (2007).

18 The estimation output is shown in the second column of Table A1 in the Appendix.

${ }^{19}$ Using oral skills instead of writing skills results in similar but somewhat weaker effects. While there is a high correlation between the two, more people speak well than write well.

${ }^{20}$ One could imagine that years of experience in the destination country are more valuable for young immigrants, as they may find it easier to adapt. However, I do not find any evidence in that regard.
} 
Interestingly, writing German well and having a German degree alone are not sufficient for an immigrant to earn a wage similar to that of a comparable native. That result is different from Aldashev et al.

(2008), who argue that immigrant-native wage differences for all those who completed their education in Germany are very small.

\subsubsection{Region of Origin and the Most Recent Immigrant Wave}

I add a dummy for immigrants born in advanced countries. These immigrants very likely have better outside options than immigrants from other countries and therefore could have smaller wage gaps. It may also be that immigrants from advanced countries face smaller cultural barriers or less discrimination and moreover their education may be better (for any given degree) than that of other immigrants. In fact, the regression results presented in the fourth column of Table 2 show that the gap of those born in advanced countries is one third smaller than that of other immigrants of similar characteristics. I test for additional effects for immigrants from emerging Europe ${ }^{21}$ and from the most important origin countries of recent asylum seekers $^{22}$ but do not find any difference to immigrants from other non-advanced countries. Note, however, that this may be due to the fact that there are only few observations for these subgroups, in particular for immigrants from the latter countries.

I then include a dummy for the most recent immigrant wave in order to see if their labor market experience differs from that of past waves. One reason could be the higher wage flexibility of the German labor market compared to previous periods which could allow firms to hire new immigrants at lower wages. Those who arrived after 2007 have indeed a large additional gap of 17 percentage points. Note that including the dummy has minimal effects on the coefficients of other immigrants' characteristics, which may be because only a small fraction of all migrants arrived after 2007.

\subsection{The Channels}

In the following I add more observables in order to understand better the channels that may explain the immigrants' wage gap. Immigrants on average spend more time in unemployment than natives and, if time spent in unemployment has a permanent negative wage effect for workers in general, this could contribute to the gap (Davis and von Wachter, 2011). In fact, as can be seen in the sixth column of Table 2 , every year of unemployment lowers the wage by 3.5 percentage points. However, when including the

\footnotetext{
${ }^{21}$ Poland, Hungary, Bulgaria, Romania, Croatia, Russia, Ukraine, Latvia, and Lithuania.

${ }^{22}$ Syria, Albania, Kosovo, Afghanistan, and Iraq.
} 
unemployment experience, the coefficient on the immigrant dummy decreases only very little.

Differences in time spent in unemployment explain less than 10 percent of the immigrants' wage gap. Another factor that may help explain the wage gap of immigrants is that natives are more likely to work in a job which they are trained for. If being trained for a job has wage benefits, this may explain part of the gap. The results are presented in the seventh column of Table 2. As expected, I find a positive effect, but including this variable in the regression does not alter the immigrant coefficients much and also explains less than 10 percent of the gap.

Next, I add the job autonomy variable that has been described in detail in the data section. Even when controlling for so many worker characteristics, going up one level in the autonomy scale increases the wage on average by 13 percentage points. ${ }^{23}$ Jobs with higher autonomy are less routine and codifiable, which may explain the higher wage (Autor, 2013). Note that when the autonomy level is included some (but not all) of the coefficients of the other explanatory variables become smaller. While the effect from years of experience and being a woman remains nearly the same, the returns to education and the effect of being an immigrant are halved. Hence, half of the effect of education on wages seems to result from the fact that better educated workers obtain jobs with a higher degree of autonomy. And some of the immigrants' wage gap seems to stem from the fact that immigrants, even when their other characteristics are identical, do not do the same jobs as natives. This finding is consistent with evidence of imperfect substitutability between immigrants and natives that have the same education and experience (Ottaviano and Peri, 2012). Interestingly, the effect of good German writing skills and a German degree now become insignificant, suggesting that these skills help push up the wage by allowing the immigrant to access jobs with a higher degree of autonomy. This result is in line with Aldashev et al. (2009), who argue that language skills increase wages only indirectly due to economic sector and occupation. Including the occupational autonomy increases the R-squared of the regression from 35.4 percent to 39.4 percent.

\subsection{Different Returns to Education}

Finally, I am raising the question whether, once autonomy is included and hence the quality of the job is controlled for, immigrants and natives have the same returns to education, or not. To do so, I first add an interaction term for the two education dummies. Column 9 in Table 2 shows the results. I find only very weak evidence that medium educated immigrants benefit less from education than natives, but strong

\footnotetext{
${ }^{23}$ I implicitly assume that the allocation of occupational autonomy to different education skill levels is predetermined. If this were not true, the occupational autonomy would be an endogenous state variable and the autonomy level itself depend on the wage structure so that results would be miss-specified (Autor, 2013).
} 
evidence for a lower return to high education. In a next step, I differentiate among those who have high education and a job that requires high education, i.e. I control for high quality job matches. The results in the last column show that a native with a high education job match earns 22 percent more than one without a match. ${ }^{24}$ And, if at all, having a match has an even greater advantage for immigrants. The different returns to high education are therefore caused by those without a job match. Over-education results in a higher wage for natives but not for immigrants. ${ }^{25}$ This result relates nicely to Anastassova (2010). She shows that in Germany, first, the returns to the usual years of education for an occupation are the same for natives and immigrants, and, second, that years of education above the 'typical' years have a larger positive impact on the earnings of natives than on those of immigrants. There is evidence, on the other hand, that over-education is compensated similarly in the U.K. (Lindley and Linton, 2006) and the U.S. (Chiswick and Miller, 2008).

\subsection{Other Results ${ }^{26}$}

So far many of the explanatory variables were implicitly assumed to effect natives and immigrants the same, e.g. age and experience. To test whether some of these characteristics have differential effects on wages across the two populations, I estimate a model that includes interaction terms between the immigrant dummy and all explanatory variables. I find significant but quantitatively very small differences regarding working and unemployment experience. Importantly, the effects of being trained for a job and job autonomy are identical for immigrants and natives. Another difference is worrying and deserves more attention. The wage gap for female immigrants is 50 percent larger than the gap for native women, suggesting that immigrant women face substantial barriers in the job market. ${ }^{27}$

A distinction between migrants of different waves would be interesting. Unfortunately, there are not enough observations to study immigrants from the most recent wave separately (in addition to including a shift of the constant, as done in 7.2.3). Instead, I divide the immigrants into those who arrived before 1990 and those who arrived thereafter. The gap for immigrants with good German writing skills and a German degree is the same for both groups. However, language skills and to an even larger extent a German degree are significantly more important for later immigrants. As a consequence the wage gap for immigrants without good language skills or a German degree is larger for those who arrived later. One

\footnotetext{
${ }^{24}$ Estimating a stochastic earning frontier with GSOEP data for 2000, Lang (2005) finds as well that an academic degree shifts up the wage up by around 12 percent and by 20 percent for jobs requiring an academic degree.

${ }_{25}^{25}$ See Hartog (2000) and McGuinness (2006) for in depth studies of over-education.

${ }^{26}$ The estimation output is available upon request.

${ }^{27}$ Research on wages and in particular on the wage gap between immigrants and natives considers mostly men only; two of the few exceptions are Dustmann and Schmidt (2000) and Adsera and Chiswick (2007).
} 
obvious reason for the finding is the changing nature of jobs in recent decades and the loss of many old manufacturing jobs that provided a relatively good income for many low skilled immigrants.

Finally, as an additional exercise, I replace gross wages with net wages and find, as expected, that the returns to education and the immigrant wage gap are smaller. The reason is, of course, that immigrants are concentrated in the lower part of the wage distribution and hence tend to benefit from Germany's progressive income tax system. Interestingly, the female wage gap increases considerably when measured by net wages. The increase is fully driven by married women, whose gap increases strongly.

\section{Determinants OF Job AND Autonomy Matches}

In the previous section it became clear that the occupational autonomy variable is crucial in explaining the lower wages of immigrants in Germany. The autonomy level is itself a labor market outcome and it is therefore important to understand why immigrants with the same education are doing jobs with less autonomy. Reasons for this kind of skill downgrading could be outright discrimination, details of the labor market institutions, such as the ease of converting educational degrees, or the role of networks. Skill downgrading is closely connected to the imperfect substitutability of immigrants and natives. The underlying reasons hence provide insights on the segmentation of the labor market as well. While the following analysis cannot resolve this issue fully, it contributes to a better understanding by examining the determinants of the autonomy level.

Table 3 Average Marginal Effects for Level of Occupational Autonomy

\begin{tabular}{lccccc}
\hline & Low & Low-Medium & Medium & Medium-High & High \\
\hline Migrant & $0.30^{* * *}$ & $0.20^{* * *}$ & $-0.14^{* * *}$ & $-0.27^{* * *}$ & $-0.092^{* * *}$ \\
Years in Germany & $-0.0051^{* * *}$ & $-0.0033^{* * *}$ & $0.0023^{* * *}$ & $0.0045^{* * *}$ & $0.0016^{* * *}$ \\
YiG Squared & $0.000081^{* *}$ & $0.000052^{* *}$ & $-0.000036^{* *}$ & $-0.000072^{* *}$ & $-0.000025^{* *}$ \\
Arrived after 2007 & -0.030 & -0.019 & 0.013 & 0.026 & 0.0090 \\
Advanced Country & $-0.063^{* * *}$ & $-0.041^{* * *}$ & $0.028^{* * *}$ & $0.057^{* * *}$ & $0.019 * * *$ \\
Good German Writing & $-0.12^{* * *}$ & $-0.075^{* * *}$ & $0.052^{* * *}$ & $0.10^{* * *}$ & $0.036^{* * *}$ \\
German Degree & $-0.10^{* * *}$ & $-0.067^{* * *}$ & $0.046^{* * *}$ & $0.092^{* * *}$ & $0.032^{* * *}$ \\
Medium Education & $-0.10^{* * *}$ & $-0.067^{* * *}$ & $0.046^{* * *}$ & $0.093^{* * *}$ & $0.032^{* * *}$ \\
High Education & $-0.34^{* * *}$ & $-0.22^{* * *}$ & $0.15^{* * *}$ & $0.30^{* * *}$ & $0.10^{* * *}$ \\
Experience & $-0.0055^{* * *}$ & $-0.0036^{* * *}$ & $0.0025^{* * *}$ & $0.0050^{* * *}$ & $0.0017^{* * *}$ \\
Experience Squared & $0.00010^{* * *}$ & $0.000066^{* * *}$ & $-0.000046^{* * *}$ & $-0.000092^{* * *}$ & $-0.000031^{* * *}$ \\
Female & $0.047^{* * *}$ & $0.030^{* * *}$ & $-0.021^{* * *}$ & $-0.042^{* * *}$ & $-0.014^{* * *}$ \\
Unemployment Experience & $0.028^{* * *}$ & $0.018^{* * *}$ & $-0.013^{* * *}$ & $-0.025^{* * *}$ & $-0.0087 * * *$ \\
\hline
\end{tabular}

$* * * \mathrm{p}<0.01, * * \mathrm{p}<0.05, * \mathrm{p}<0.1$

Note: The table shows average marginal effects from a logit regression for the level of occupational autonomy. Source: SOEP 1984-2013. 
I first estimate an ordered logit model with the level of autonomy as the dependent variable. Table 3 reports the average marginal effects for the different levels of autonomy. Accordingly, based on the estimated coefficients, an immigrant is on average 30 percent more likely than a native to have a job with low autonomy conditional on the other included variables. As for wages, the "immigrant penalty" becomes smaller over time, but assimilation is minimal: after 20 years the average marginal effect from being an immigrant is still 23 percent. Only an immigrant who writes German well, has a German degree, and is born in an advanced country has a probability as low as a native to obtain a job with a low level of autonomy. Looking at high autonomy, immigrants are 9 percentage points less likely to have high autonomy job and, again, the effect remains strong over time. Immigrants with a German degree and writing skills and those born in advanced countries perform better than other immigrants.

Interestingly, in contrast with the wage regressions, immigrants arriving after 2007 have no additional disadvantage compared to other immigrants. The effect is insignificant and the sign even points to the opposite. This result is somewhat surprising and suggests that recent immigrants earn less than natives for doing the same jobs. Note that the extra penalty for those who arrived after 2007 in the wage equations in Section 7 stays constant when autonomy is included in the regression.

How large is the effect of being an immigrant on the autonomy level compared to other characteristics? Note that education is the most important factor, with high education being much more important than medium education. A highly educated person is 34 percentage points less likely to have low autonomy, 22 percentage points less likely to have low-medium autonomy, 15 percentage points more likely have medium autonomy, 31 percentage points more likely to have medium-high autonomy and 10 percentage points more likely to have high autonomy. The respective average marginal effects of being an immigrant not born in an advanced country are 30 percentage points, 20 percentage points, minus 13 percentage points, minus 27 percentage points and minus 9 percentage points. In contrast to substantial differences between immigrants from advanced and non-advanced countries regarding wages, the effect here is much smaller. Such a pattern could arise if highly educated immigrants from advanced countries, while performing worse than natives regarding autonomy, at least do jobs that require their high education whereas those from non-advanced countries do not.

In fact, over two-thirds of highly skilled natives have a job matching their qualification and this fraction is even a bit higher for immigrants from advanced countries. In contrast, only 42 percent of the other immigrants have a good job match. When looking at high autonomy instead of job matches, the fraction 
decreases slightly for natives, but it remains above 60 percent. The decrease is stronger for immigrants born in advanced countries, but still half of them have a high autonomy. The same is true for only onethird of the other immigrants. The probabilities are only conditioned on high education and do not account for differences in other characteristics, which could explain why fewer immigrants from nonadvanced countries have high autonomy. Since it is widely believed that highly educated immigrants are needed the most in the German labor market and since these are at the same time the ones penalized most, I explore their performance further and I estimate three simple logit models. First, looking only at highly skilled immigrants, I employ a dichotomous dependent variable that is one when the immigrant has a job that requires high education and zero otherwise; second, I replace the dependent variable with a dummy that is equal to one in case the immigrant has high autonomy; and, third, I look at medium educated immigrants and use a dummy as dependent variable that is one if they have at least medium autonomy and zero otherwise. Table A2 in the Appendix shows the average marginal effects. It report the change in probability due to working in a particular industry as well; the omitted category and therefore benchmark is working in Services.

While the years spent in Germany make it more likely for a medium educated immigrant to have a job with at least medium autonomy, there is no positive effect for highly educated immigrants. Surprisingly, the level of experience has even negative effects for highly skilled immigrants. For medium educated immigrants, on the other hand, there is again a positive effect, i.e. for them working for many years and gaining experience and obtaining human capital in the country translates into better jobs with higher autonomy and consequently higher wages. This prospect is absent for well-educated immigrants. As suspected, being born in an advanced country has a larger effect on having a job match than high autonomy. The opposite is true for a German degree that has a larger average marginal effect for having high autonomy. A German degree is particularly important for medium educated immigrants. In contrast to medium educated women, highly educated ones have a disadvantage over men, with a stronger effect for high autonomy than job matches. Finally, there are some industries in which over-education and skill downgrading seem particularly common. For highly skilled immigrants these are Manufacturing and Trade, whether one looks at matches or high autonomy. For medium educated immigrants the sectors with the worst performing immigrants are in decreasing order Manufacturing, Transport, Mining (only at 10 percent significance level), and Construction. On the other hand, medium educated immigrants working in Banking and Insurances are over 30 percentage points more likely than those working in Services to have at least medium autonomy. 


\section{UNEMPLOYMENT AND PARTICIPATION}

Wage performance, often the main focus in the literature, is clearly an important measure for the labor market performance of immigrants. However, unemployment and participation of immigrants are major policy concerns as well. Working eases the adjustment in the destination country (Hansen, 2012), reduces the use of fiscal transfers and increases the contribution to the economy and the fiscal budget (Hinte and Zimmermann, 2014; Dustmann and Frattini, 2014). Moreover, it also affects how immigrants are perceived by natives (Hainmüller and Hopkins, 2014). In this section, I therefore look deeper into whether labor market participation among immigrants is as high as among natives (given other characteristics), whether being an immigrant translates into a higher probability of being unemployed, and what characteristics are important. To do so, I estimate logit models with either unemployment or participation as the dichotomous dependent variable. I use the full sample and control for the region, age, and the survey year. As before, standard errors are clustered at the individual level.

Table 4 reports the average marginal effects for unemployment in columns (1) and (2). With every year of experience, the probability of being unemployed is reduced by 0.1 percentage points. Medium education reduces the probability by 1.3

Figure 4 Assimilation of Unemployment and Participation

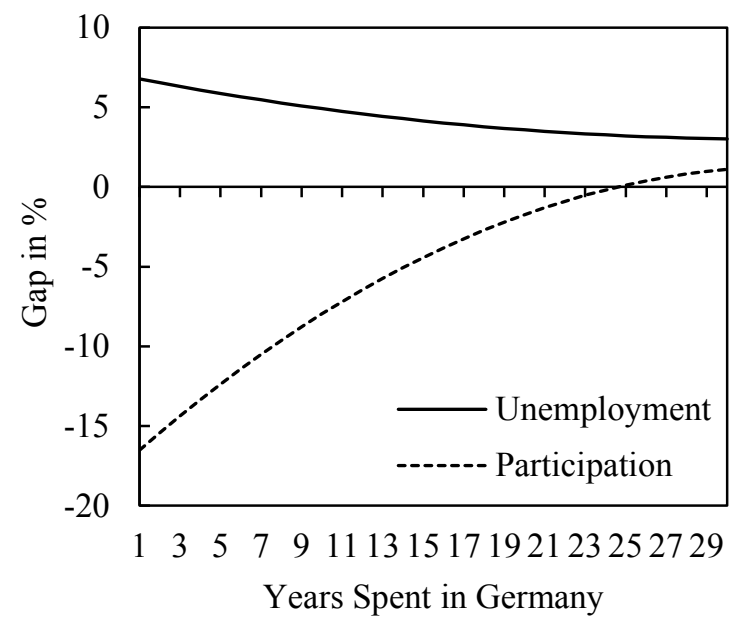

Note: Assimilation paths from logit regressions (see Table 4). Source: SOEP 1984-2013, own calculations percentage points and high education by 6.2 percentage points. Being a woman reduces the likelihood by 1.1 percentage points, which could result from the fact that women who are not working tend to drop out of the labor force if they do not find employment. Given these characteristics and the controls, an immigrant after arrival has a much higher probability $(6.8$ additional percentage points) to be unemployed than a native. To put this number into perspective, the average unemployment rate of natives over the whole sample was lower than 6.8 percent. Figure 4 plots the immigrants' average marginal effect for being unemployed. While with acquisition of experience in the country the effect decreases, it remains permanently positive and above 3 percentage points. An initially higher unemployment rate of immigrants is not surprising. For example, if 
immigrants have lower skills than natives when they enter the job market but then learn the skills for better paying jobs over time, they are more likely to change the job more often, which would in any period of the time result in a higher frictional unemployment rate (Chiswick and others, 1997). A permanent effect, on the other hand, is very worrisome and points to persistent labor market frictions for immigrants. In the U.S. the unemployment difference is not permanent and vanishes already after three years (Chiswick and others, 1997).

Table 4 Average Marginal Effects for Unemployment and Participation

\begin{tabular}{|c|c|c|c|c|}
\hline & \multicolumn{2}{|c|}{ Unemployment Rate } & \multicolumn{2}{|c|}{ Participation Rate } \\
\hline & $(1)$ & $(2)$ & (3) & (4) \\
\hline Experience & $\begin{array}{c}-0.0011 * * * \\
(0.00020)\end{array}$ & $\begin{array}{c}-0.0013 * * * \\
(0.00020)\end{array}$ & $\begin{array}{l}0.014 * * * \\
(0.00035)\end{array}$ & $\begin{array}{l}0.014 * * * \\
(0.00035)\end{array}$ \\
\hline Experience Squared & $\begin{array}{c}7.7 \mathrm{e}-06 \\
(5.0 \mathrm{e}-06)\end{array}$ & $\begin{array}{c}0.000014 * * * \\
(5.0 \mathrm{e}-06)\end{array}$ & $\begin{array}{c}-0.00026 * * * \\
(8.3 \mathrm{e}-06)\end{array}$ & $\begin{array}{c}-0.00026^{* * *} \\
(8.3 \mathrm{e}-06)\end{array}$ \\
\hline Migrant & $\begin{array}{c}0.068 * * * \\
(0.0052)\end{array}$ & $\begin{array}{c}0.069 * * * \\
(0.0085)\end{array}$ & $\begin{array}{l}-0.18 * * * \\
(0.0094)\end{array}$ & $\begin{array}{c}-0.15 * * * \\
(0.014)\end{array}$ \\
\hline Born in Advanced Country & & $\begin{array}{c}-0.020 * * * \\
(0.0036)\end{array}$ & & $\begin{array}{c}0.038 * * * \\
(0.0066)\end{array}$ \\
\hline Years in Germany & $\begin{array}{c}-0.0024 * * * \\
(0.00047)\end{array}$ & $\begin{array}{c}-0.00097 * * \\
(0.00046)\end{array}$ & $\begin{array}{l}0.014 * * * \\
(0.00092)\end{array}$ & $\begin{array}{l}0.013 * * * \\
(0.00094)\end{array}$ \\
\hline YiG Squared & $\begin{array}{c}0.000039 * * * \\
(9.7 \mathrm{e}-06)\end{array}$ & $\begin{array}{c}0.000020 * * \\
(9.7 \mathrm{e}-06)\end{array}$ & $\begin{array}{c}-0.00024 * * * \\
(0.000020)\end{array}$ & $\begin{array}{c}-0.00024 * * * \\
(0.000021)\end{array}$ \\
\hline Medium Education (ME) & $\begin{array}{c}-0.013 * * * \\
(0.0020)\end{array}$ & $\begin{array}{c}-0.018^{* * *} \\
(0.0024)\end{array}$ & $\begin{array}{c}0.037 * * * \\
(0.0034)\end{array}$ & $\begin{array}{c}0.034 * * * \\
(0.0040)\end{array}$ \\
\hline Migrant with ME & & $\begin{array}{c}0.0095 * * \\
(0.0042)\end{array}$ & & $\begin{array}{c}0.0081 \\
(0.0077)\end{array}$ \\
\hline High Education (HE) & $\begin{array}{c}-0.062 * * * \\
(0.0029)\end{array}$ & $\begin{array}{c}-0.073 * * * \\
(0.0033)\end{array}$ & $\begin{array}{c}0.097 * * * \\
(0.0042)\end{array}$ & $\begin{array}{c}0.092 * * * \\
(0.0047)\end{array}$ \\
\hline Migrant with $\mathrm{HE}$ & & $\begin{array}{c}0.049 * * * \\
(0.0066)\end{array}$ & & $\begin{array}{l}0.020 * \\
(0.012)\end{array}$ \\
\hline Female & $\begin{array}{c}-0.011 * * * \\
(0.0018)\end{array}$ & $\begin{array}{c}-0.011 * * * \\
(0.0019)\end{array}$ & $\begin{array}{c}-0.094 * * * \\
(0.0032)\end{array}$ & $\begin{array}{c}-0.094 * * * \\
(0.0032)\end{array}$ \\
\hline Good German Writing & & $\begin{array}{c}-0.022 * * * \\
(0.0046)\end{array}$ & & $\begin{array}{c}0.014 \\
(0.0091)\end{array}$ \\
\hline German Degree & & $\begin{array}{c}-0.012 * * * \\
(0.0040)\end{array}$ & & $\begin{array}{c}-0.012 \\
(0.0077)\end{array}$ \\
\hline Im. Unemployment Rate & & $\begin{array}{l}-0.00024 \\
(0.00090) \\
\end{array}$ & & $\begin{array}{c}-0.0034 * * * \\
(0.0013)\end{array}$ \\
\hline Controls & YES & YES & YES & YES \\
\hline Observations & 351,010 & 351,010 & 351,010 & 351,010 \\
\hline
\end{tabular}

Standard errors in parentheses; *** $\mathrm{p}<0.01, * * \mathrm{p}<0.05, * \mathrm{p}<0.1$

As controls I include the region, the age, as well as year dummies.

Note: Estimation output from logit regression with unemployment or participation as dependent variable. Source: SOEP 1984-2013. 
Column (2) considers different characteristics of immigrants in the same way as in the previous wage equations. An immigrant from an advanced country with a German degree and who writes German well has the smallest penalty (1.5 percentage points). Not being born in an advanced country increases the penalty to 3.5 percentage points, not writing German to 5.7 percentage points, and not having a German degree to 6.9 percentage points. The effects of education are different for natives and immigrants. The latter benefit again substantially less from their education. I add an interaction term of being an immigrant and the economy-wide unemployment rate in order to see whether immigrants are more sensitive to changes in the rate. It could be the case, for example, that immigrants are over-represented in sectors particularly vulnerable during economic downturns (Kogan, 2004). However, I do not find any significant effects.

I repeat the same regressions now with participation as the dependent variable and report the results in columns (3) and (4). Initially, every year of experience increases the probability to participate in the labor market by 1.4 percentage points, but the effect is decreasing over time. Medium education has a positive effect of 3.7 percentage points and high education of 9.7 percentage points. Given these characteristics, women are participating less; their probability to participate is 9.4 percentage points lower than that of men. An immigrant who just arrived in Germany is 18 percentage points less likely to participate but catches up over time. ${ }^{28}$ Figure 4 plots the assimilation path. After 15 years the difference is down to less than 5 percentage points, after 20 years it is below 1 percentage point and after 22 years it is zero. In contrast to wages and unemployment, participation hence fully converges. This is an important result because it shows that immigrants want to work. It is also not necessarily expected given the fact that Germany has relatively high female labor market participation in international comparison (though women tend to work part time). Antecol (2000) shows that the participation of migrant women is correlated with their participation rate in their home countries. A full convergence means that even such cultural differences are compensated within one generation. ${ }^{29}$ Chiswick and others (1997) find full assimilation in the U.S. as well and at a faster rate than in Germany (10 years).

Next, I compare different immigrants. In contrast to the probability of being unemployed, neither a degree from Germany nor German writing skills affect the decision to participate. Moreover, the effects of education are the same for natives and immigrants. Only the origin of the immigrants matters. The gap of

\footnotetext{
${ }^{28}$ It is often argued that one reason for the lower participation rate after arrival is that immigrants are taking courses, for example language courses. While certainly true, I excluded all persons in education or training from the analysis so that this effect is minimized.

${ }^{29}$ Also Antecol (2000), who studies the US, finds assimilation over time. However, she does not find full convergence within one generation.
} 
immigrants born in advanced countries is 25 percent smaller than that of other immigrants. Somewhat surprisingly, the participation rate of immigrants - in contrast to the probability of being unemployed - is more sensitive to the overall unemployment rate in the economy, but the effect is rather small quantitatively.

\section{ROBustness CHECKS}

Regarding the robustness of the results presented above, one could wonder to what extent the use of the individual sample weights matters. Or one could be interested to what extent the uncertainty about the survey structure increases the uncertainty of the estimates. I therefore re-estimate the most elaborate specification of the wage equation, which necessarily breaks down the sample into the smallest subgroups, first, without the weights and, second, using the random group variance estimator (as described in Wolters, 2007). The latter estimator offers an alternative for the SOEP, as participants are sorted in random groups during data collection. Table A3 in the Appendix reports the results. When the model is estimated without the weights, the wage gap for immigrants becomes somewhat smaller and as a quid pro quo the returns to education of immigrants go down. The effects of being born in an advanced country and having migrated after 2007 become smaller as well. All other coefficients remain either the same or change only minimally. While the results are not identical, they are not changing fundamentally. Given that the individual weights have recently been improved due to the new information available from the Census 2011, I prefer the specification with weights as the benchmark. The use of the random group variance estimator tells us whether the survey structure has implications for the uncertainty of our estimates. In general, standard errors are very similar, but not without exception. In particular, while the catching-up process is highly statistically significant using clustered standard errors, it is only significant at the 10 percent level using the random group variance estimator. However, when switching to a specification with fewer interaction terms, the linear term is again significant at the 2 percent level and the quadratic term at the 7 percent level.

I also re-estimate the wage equation using the Heckman correction method in order to correct for selection bias. More specifically, in the first stage regression I estimate the likelihood that the individual is in work and in the second stage I estimate the wage regression conditional on being in work. The results indicate that my results are not distorted by a selection bias. I hence do not report these results. ${ }^{30}$

\footnotetext{
${ }^{30}$ Even Adsera and Chiswick (2007), who focus much more on women than this paper, do not correct for the selection bias in their main specification.
} 
As an additional robustness check, I re-estimate the models presented in Section 8 and Section 9 with probit instead of logit models. The probit regressions have a somewhat lower likelihood, which is why the results from the logit models are reported. In any case the results are nearly identical and the specification does not matter for the results. ${ }^{31}$

In summary, all the results reported above are very robust to different model specifications or estimation techniques. Furthermore, there is no sample selection bias for immigrants.

\section{CONCLUSION}

This paper provides an analysis of the labor market performance of immigrants in Germany. While immigrants make substantial contributions to the economy, this paper shows that they face more obstacles in the labor market than native workers, and that these obstacles are overcome only gradually and never fully. Some of the findings in this paper are relevant for the current policy debates in Germany. For instance, it is often argued that highly skilled immigrants are the most needed by German employers, and that Germany is not yet a prime destination for these immigrants compared to countries like the U.K., the U.S., or Canada. This paper has shown that highly skilled immigrants experience sizable skill downgrading and relatively large and persistent wage gaps in Germany. To attract highly-skilled immigrants, therefore, it is essential to understand better why such downgrading takes place and see if policies can reduce obstacles to skill transfer.

Another important topic is how the current large wave of refugees will fare in the labor market. The findings in this paper indicate that they may face bigger obstacles than the average immigrant from the past. While we still do not know a lot about the current wave of refugees, preliminary evidence points to lower education and qualification levels than for other immigrants (IAB, 2015). In addition, they come from non-advanced countries and they likely have no German degrees and cannot write German well. This analysis has shown that these immigrants - even conditional on characteristics like education and experience - are less likely to participate in the labor market and are more likely to be unemployed than other immigrants. Moreover, when they find work, they initially earn 30 percent less than otherwise similar natives. While these gaps decrease over time, the process is slow and immigrants remain more likely to be unemployed throughout. The recent introduction of the minimum wage may lower the wage gap of new immigrants, but at the same time may further increase their likelihood of being unemployed (Battisti and Felbermayr, 2015). While the recent influx of refugees helps to address a severe

\footnotetext{
${ }^{31}$ Results can be requested from the author.
} 
humanitarian crisis and constitutes an opportunity for boosting working age population in Germany, successful labor market integration of the newcomers must not be taken for granted. It will likely need some time, particular efforts, and decisive policy action. 


\section{REFERENCES}

Adsera, A., \& Chiswick, B. R. (2007). Are there gender and country of origin differences in immigrant labor market outcomes across European destinations?. Journal of Population Economics, 20(3), 495526.

Akresh, I. R. (2008). Occupational trajectories of legal US immigrants: Downgrading and recovery. Population and Development Review, 34(3), 435-456.

Aldashev, A., Gernandt, J., \& Thomsen, S. L. (2008). The immigrant wage gap in Germany. ZEW-Centre for European Economic Research Discussion Paper, (08-089).

Aldashev, A., Gernandt, J., \& Thomsen, S. L. (2009). Language usage, participation, employment and earnings: Evidence for foreigners in West Germany with multiple sources of selection. Labour Economics, 16(3), 330-341.

Algan, Y., Dustmann, C., Glitz, A., \& Manning, A. (2010). The economic situation of first and secondgeneration immigrants in France, Germany and the United Kingdom. The Economic Journal, 120(542), F4-F30.

Anastassova, L. (2010). Are Immigrants Paid Less for Education?. CERGE-EI Working Paper Series, (406).

Antecol, H. (2000). An examination of cross-country differences in the gender gap in labor force participation rates. Labour Economics, 7(4), 409-426.

Battisti, M., Felbermayr, G. (2015), Migranten im deutschen Arbeitsmarkt: Löhne, Arbeitslosigkeit, Erwerbsquoten, ifo Schnelldienst 20/2015, S. 39-47.

Bauer, T., \& Zimmermann, K. F. (1997). Unemployment and wages of ethnic Germans. The Quarterly Review of Economics and Finance, 37, 361-377.

Bauer, T., Dietz, B., Zimmermann, K. F., \& Zwintz, E. (2005). German migration: Development, assimilation, and labour market effects. In European Migration: What do we know?. Oxford University Press, Oxford 197-261.

Basilio L., Bauer, K. \& Kramer A. (2014). Transferability of Human Capital and Immigrant Assimilation: An Analysis for Germany (No. 671). SOEPpaper

Becketti, S., Gould, W., Lillard, L., \& Welch, F. (1988). The panel study of income dynamics after fourteen years: An evaluation. Journal of Labor Economics, 472-492.

Behr, A., Bellgardt, E., \& Rendtel, U. (2005). Extent and determinants of panel attrition in the European Community Household Panel. European Sociological Review, 21(5), 489-512.

Bertoli, S., Brücker, H., \& Moraga, J. F. H. (2013). The European Crisis and Migration to Germany: Expectations and the Diversion of Migration Flows.

Bleakley, H., \& Chin, A. (2004). Language skills and earnings: Evidence from childhood immigrants. Review of Economics and statistics, 86(2), 481-496.

Borjas, G. J. (1999). The economic analysis of immigration. Handbook of Labor Economics, 3, $1697-$ 1760.

Brenke, K. \& Mueller, K.-U. (2013). Gesetzlicher Mindestlohn - Kein Verteilungspolitisches Allheilmittel. DIW Wochenbericht (39), 3-17.

Brücker, H. and others (2014). The new IAB-SOEP Migration Sample: an introduction into the methodology and the contents (No. 216). SOEP Survey Papers. 
Büchel, F., \& Frick, J. R. (2004). Immigrants in the UK and in West Germany-Relative income position, income portfolio, and redistribution effects. Journal of Population Economics, 17(3), 553-581.

Chiswick, B. R. (1978). The effect of Americanization on the earnings of foreign-born men. The Journal of Political Economy, 897-921.

Chiswick, B. R., Cohen, Y., \& Zach, T. (1997). The labor market status of immigrants: Effects of the unemployment rate at arrival and duration of residence. Industrial \& Labor Relations Review, 50(2), 289-303.

Chiswick, B. R., \& Miller, P. W. (2008). Why is the payoff to schooling smaller for immigrants?. Labour Economics, 15(6), 1317-1340.

Chiswick, B. R., \& Miller, P. W. (2009). The international transferability of immigrants' human capital. Economics of Education Review, 28(2), 162-169.

Constant, A., \& Massey, D. S. (2005). Labor market segmentation and the earnings of German guestworkers. Population Research and Policy Review, 24(5), 489-512.

Davis, S. J., \& von Wachter, T. M. (2011). Recessions and the cost of job loss (No. w17638). National Bureau of Economic Research.

De la Rica, S., Glitz A. \& Ortega F. (2013). Immigration in Europe: Trends, Policies and Empirical Evidence (No. 7778). IZA Discussion Paper.

Dustmann, C. (1993). Earnings adjustment of temporary migrants. Journal of Population Economics, 6(2), 153-168.

Dustmann, C. (2000). Temporary migration and economic assimilation (No. 186). IZA Discussion Paper Series.

Dustmann, C., \& Frattini, T. (2011). Immigration: The European Experience (No. 6261). IZA Discussion Paper Series.

Dustmann, C., \& Frattini, T. (2014). The fiscal effects of immigration to the UK. The Economic Journal, 124(580), 593-643.

Dustmann, C., \& Schmidt, C. M. (2000). The wage performance of immigrant women: Full-time jobs, part-time jobs, and the role of selection (No. 233). IZA Discussion Paper Series.

Dustmann, C., \& Van Soest, A. (2001). Language fluency and earnings: Estimation with misclassified language indicators. Review of Economics and Statistics, 83(4), 663-674.

Dustmann, C., \& Van Soest, A. (2002). Language and the Earnings of Immigrants. Industrial \& Labor Relations Review, 55(3), 473-492.

Dustmann, C., Frattini, T., \& Preston, I. P. (2013). The effect of immigration along the distribution of wages. The Review of Economic Studies, 80(1), 145-173.

Falck, O., Knabe, A., Mazat, A., \& Wiederhold, S. (2013). Mindestlohn in Deutschland: Wie viele sind betroffen?. ifo Schnelldienst, 66(24), 68-73.

Fertig, M. \& Schurer, A. (2007). Labour Market Outcomes of Immigrants in Germany: The Importance of Heterogeneity and Attrition Bias (No. 2915). IZA Discussion Paper Series.

Federal Ministry of the Interior - Bundesministerium des Innern (2015). Migrationsbericht des Bundesamtes für Migration und Flüchtlinge im Auftrag der Bundesregierung (Migrationsbericht 2013). Berlin.

Gathmann, C., \& Keller, N. (2014). Returns to Citizenship? Evidence from Germany's Recent Immigration Reforms (No. 8064). IZA Discussion Paper Series. 
Gathmann, C., Keller, N., Monscheuer, O., Straubhaar, T., Schäfer, H., Zimmermann, K. F., \& Brücker, H. (2014). Zuwanderung nach Deutschland-Problem und Chance für den Arbeitsmarkt. Wirtschaftsdienst, 94(3), 159-179.

Gundel, S., and Peters, H. (2007). Assimilation and Cohort Effects for German Immigrants, SOEP Paper, No. 64

Hansen, R. (2012). The Centrality of Employment in Immigrant Integration in Europe. Washington DC: Migration Policy Institute.

Hainmüller, J., \& Hopkins, D. J. (2014). Public Attitudes Toward Immigration. Annual Review of Political Science, 17, 225-249.

Hartog, J. (2000). Over-education and earnings: where are we, where should we go?. Economics of Education Review, 19(2), 131-147.

Hausman, J. A., \& Wise, D. A. (1979). Attrition bias in experimental and panel data: the Gary income maintenance experiment. Econometrica: Journal of the Econometric Society, 455-473.

Hinte, H., \& Zimmermann, K. F. (2014). Does the calculation hold? The fiscal balance of migration to Denmark and Germany (No. 87). IZA Policy Paper.

Hoffmeyer-Zlotnik, Jürgen H.P., and Alfons J. Geis (2003) Berufsklassifikation und Messung des beruflichen Status/ Prestige. In: ZUMANachrichten 52, Jg. 27, Mai 2003. pp. 125-138.

IAB (2015), Flüchtlinge und andere Migranten am deutschen Arbeitsmarkt: Der Stand im September 2015, Aktuelle Berichte 14/2015

Knabe, A. \& Schöb, R. (2009). Minimum Wage Incidence: The Case for Germany. FinanzArchiv/Public Finance Analysis 65(4), 403-441.

Kogan, I. (2004). Last hired, first fired? The unemployment dynamics of male immigrants in Germany. European Sociological Review, 20(5), 445-461.

Lang, G. (2005). The difference between wages and wage potentials: Earnings disadvantages of immigrants in Germany. The Journal of Economic Inequality, 3(1), 21-42.

Lehmer, F., \& Ludsteck, J. (2011). The immigrant wage gap in Germany: Are East Europeans worse off?. International Migration Review, 45(4), 872-906.

Lehmer, F., \& Ludsteck, J. (2014). Wage assimilation of foreigners: Which factors close the gap? Evidence from Germany. Review of Income and Wealth.

Lillard, L. A., \& Panis, C. W. (1998). Panel attrition from the Panel Study of Income Dynamics: Household income, marital status, and mortality. Journal of Human Resources, 437-457.

Lindley, L. and Lenton, P. (2006). The over-education of UK Immigrants: evidence from the Labour Force Survey. Sheffield Economic Research paper Series, SEPR No. 2006001

McGuinness, S. (2006). Overeducation in the labour market. Journal of Economic Surveys, 20(3), 387418.

Meng, R. (1987). The earnings of Canadian immigrant and native-born males. Applied Economics, 19(8), $1107-1119$.

Mühleisen, M., \& Zimmermann, K. F. (1994). A panel analysis of job changes and unemployment. European Economic Review, 38(3), 793-801.

Müller, K. U. (2009). How Robust Are Simulated Employment Effects of a Legal Minimum Wage in Germany?: A Comparison of Different Data Sources and Assumptions. 
Ottaviano, G. I., \& Peri, G. (2012). Rethinking the effect of immigration on wages. Journal of the European Economic Association, 10(1), 152-197.

Pischke, J. S. (1992). Assimilation and the Earnings of Guestworkers in Germany (No. 92-17). ZEW Discussion Papers.

Schmidt, C. M. (1997). Immigrant performance in Germany: Labor earnings of ethnic German migrants and foreign guest-workers. The Quarterly Review of Economics and Finance, 37, 379-397.

SOEP Group. (2001). The German Socio-Economic Panel (GSOEP) after more than 15 years: overview. Vierteljahrshefte zur Wirtschaftsforschung, 70(1), 7-14.

Uhlendorff, A., \& Zimmermann, K. F. (2014). Unemployment dynamics among migrants and natives. Economica, 81(322), 348-367.

Wagner, G. G., Frick J. R. \& Schupp, J. (2007). The German Socio-Economic Panel Study (SOEP) Scope, Evolution and Enhancements. Schmollers Jahrbuch 127(1), 139-169.

Wolter, K. (2007). Introduction to variance estimation. Springer Science \& Business Media, New York

Zibrowius, M. (2012). Convergence or divergence? Immigrant wage assimilation patterns in Germany. Immigrant Wage Assimilation Patterns in Germany (No. 479). SOEPpaper. 


\section{APPENDIX}

Table A1 Immigrant Personal Fixed-Effects Estimation Output

\begin{tabular}{|c|c|c|}
\hline & $(1)$ & $(2)$ \\
\hline Experience & $\begin{array}{l}0.016^{* * * *} \\
(0.0026)\end{array}$ & $\begin{array}{c}0.016^{* * *} \\
(0.0026)\end{array}$ \\
\hline Experience Squared & $\begin{array}{c}-0.00033 * * * \\
(0.000038)\end{array}$ & $\begin{array}{c}-0.00033 * * * \\
(0.000038)\end{array}$ \\
\hline Medium Education & $\begin{array}{l}0.034 * \\
(0.020)\end{array}$ & $\begin{array}{l}0.036^{*} \\
(0.020)\end{array}$ \\
\hline High Education & $\begin{array}{c}0.10 * * * \\
(0.030)\end{array}$ & $\begin{array}{c}0.100 * * * \\
(0.030)\end{array}$ \\
\hline Years in Germany & $\begin{array}{c}0.0097 * * * \\
(0.0025)\end{array}$ & \\
\hline Years in Germany Squared & $\begin{array}{c}-0.00011 * * * \\
(0.000042)\end{array}$ & \\
\hline Years in Germany $\mathrm{C} 1$ & & $\begin{array}{c}0.0048 \\
(0.0085)\end{array}$ \\
\hline Years in Germany Squared C1 & & $\begin{array}{l}-0.000012 \\
(0.00013)\end{array}$ \\
\hline Years in Germany C2 & & $\begin{array}{c}0.0048 \\
(0.0070)\end{array}$ \\
\hline Years in Germany Squared C2 & & $\begin{array}{l}-0.000041 \\
(0.00013)\end{array}$ \\
\hline Years in Germany C3 & & $\begin{array}{l}0.013 * * \\
(0.0056)\end{array}$ \\
\hline Years in Germany Squared C3 & & $\begin{array}{l}-0.00020 \\
(0.00013)\end{array}$ \\
\hline Years in Germany C4 & & $\begin{array}{c}0.016^{* * *} \\
(0.0060)\end{array}$ \\
\hline Years in Germany Squared C4 & & $\begin{array}{l}-0.00030 \\
(0.00022)\end{array}$ \\
\hline Observations & 34,322 & 34,322 \\
\hline R-squared & 0.072 & 0.072 \\
\hline Number of Persons & 6,911 & 6,911 \\
\hline Controls & YES & YES \\
\hline \multicolumn{3}{|l|}{ Robust standard errors in parentheses } \\
\hline $\begin{array}{l}* * * \mathrm{p}<0.01, * * \mathrm{p}<0.05, * \mathrm{p}<0.1 \\
\text { As controls we include the region } \\
\text { the age, and the number of years in } \\
\text { industry dummies. }\end{array}$ & $\begin{array}{l}\text { person is mar } \\
\text { addition, I ir }\end{array}$ & $\begin{array}{l}\text { vorks full time, } \\
\text { years and }\end{array}$ \\
\hline
\end{tabular}

Note: This estimation is similar to column 2 in Table 2 but the sample is restricted to immigrants and personal fixed effects are included. $\mathrm{C} 1$ to $\mathrm{C} 4$ refers to the four different cohorts.

Source: SOEP 1984-2013, own calculations. 
Table A2 Average Marginal Effects for Matches and High/Medium Autonomy

\begin{tabular}{|c|c|c|c|}
\hline & \multicolumn{2}{|c|}{ High Education } & \multirow{2}{*}{$\begin{array}{l}\text { Medium Education } \\
\text { Med./High. Aut. }\end{array}$} \\
\hline & Match & High Aut. & \\
\hline & (1) & (2) & (3) \\
\hline \multirow[t]{2}{*}{ Years in Germany } & 0.00380 & 0.000217 & $0.0115 * * *$ \\
\hline & $(0.00546)$ & $(0.00501)$ & $(0.00369)$ \\
\hline \multirow[t]{2}{*}{ YiG Squared } & $-8.99 \mathrm{e}-06$ & $-4.95 e-05$ & $-0.000158^{*}$ \\
\hline & $(0.000115)$ & $(0.000100)$ & $(8.42 \mathrm{e}-05)$ \\
\hline \multirow[t]{2}{*}{ Arrived after 2007} & 0.0490 & 0.133 & $0.127 *$ \\
\hline & $(0.0881)$ & $(0.0920)$ & $(0.0740)$ \\
\hline \multirow[t]{2}{*}{ Advanced Country } & $0.135 * * *$ & $0.227 * * *$ & $0.104 * * *$ \\
\hline & $(0.0429)$ & $(0.0401)$ & $(0.0329)$ \\
\hline \multirow[t]{2}{*}{ German Degree } & $0.119 * * *$ & $0.0846^{* *}$ & $0.145^{* * *}$ \\
\hline & $(0.0431)$ & $(0.0427)$ & $(0.0307)$ \\
\hline \multirow[t]{2}{*}{ Good German Writing } & $0.0935 * * *$ & $0.386 * * *$ & $0.0528 * *$ \\
\hline & $(0.0318)$ & $(0.0575)$ & $(0.0243)$ \\
\hline \multirow[t]{2}{*}{ Experience } & $-0.0152 * *$ & $-0.0193 * * *$ & $0.00666^{*}$ \\
\hline & $(0.00610)$ & $(0.00641)$ & $(0.00343)$ \\
\hline \multirow[t]{2}{*}{ Experience Squared } & 0.000118 & $8.47 e-05$ & $-0.000181 * *$ \\
\hline & $(0.000147)$ & $(0.000128)$ & $(8.04 \mathrm{e}-05)$ \\
\hline \multirow[t]{2}{*}{ Female } & $-0.239 * * *$ & $-0.136 * * *$ & -0.0359 \\
\hline & $(0.0373)$ & $(0.0407)$ & $(0.0307)$ \\
\hline \multirow[t]{2}{*}{ Age } & $0.00705 * *$ & $0.0125 * * *$ & $-0.00467 * *$ \\
\hline & $(0.00316)$ & $(0.00332)$ & $(0.00222)$ \\
\hline \multirow[t]{2}{*}{ Unemployment Experience } & $-0.0547 * * *$ & $-0.0402 * * *$ & $-0.0407 * * *$ \\
\hline & $(0.0200)$ & $(0.0155)$ & $(0.00851)$ \\
\hline \multirow[t]{2}{*}{ Works in Agriculture } & 0.0882 & -0.0464 & $-0.318 * * *$ \\
\hline & $(0.119)$ & $(0.142)$ & $(0.0703)$ \\
\hline \multirow[t]{2}{*}{ Works in Energy } & 0.00268 & -0.142 & -0.174 \\
\hline & $(0.128)$ & $(0.165)$ & $(0.129)$ \\
\hline \multirow[t]{2}{*}{ Works in Mining } & - & - & $-0.166^{*}$ \\
\hline & - & - & $(0.0939)$ \\
\hline \multirow[t]{2}{*}{ Works in Manufacturing } & $-0.137 * * *$ & $-0.242 * * *$ & $-0.263 * * *$ \\
\hline & $(0.0453)$ & $(0.0462)$ & $(0.0335)$ \\
\hline \multirow[t]{2}{*}{ Works in Construction } & -0.0300 & -0.0647 & $-0.127 * * *$ \\
\hline & $(0.0695)$ & $(0.0478)$ & $(0.0360)$ \\
\hline \multirow[t]{2}{*}{ Works in Trade } & $-0.220 * * *$ & $-0.390 * * *$ & -0.0619 \\
\hline & $(0.0743)$ & $(0.0909)$ & $(0.0400)$ \\
\hline \multirow[t]{2}{*}{ Works in Transport } & -0.0500 & -0.152 & $-0.182 * * *$ \\
\hline & $(0.106)$ & $(0.0999)$ & $(0.0448)$ \\
\hline \multirow[t]{2}{*}{ Works in Bank and Insurances } & -0.210 & -0.202 & $0.326^{* *}$ \\
\hline & $(0.174)$ & $(0.155)$ & $(0.151)$ \\
\hline Controls & YES & YES & YES \\
\hline Observations & 5,010 & 5,010 & 15,599 \\
\hline
\end{tabular}

Standard errors in parentheses; $* * * \mathrm{p}<0.01,{ }^{* *} \mathrm{p}<0.05,{ }^{*} \mathrm{p}<0.1$

As controls I include missing values for industry, year dummies, the region, whether the person works full-time and is married, as well as the years in the firm.

Note: Average marginal effects from logit models.

Source: SOEP 1984-2013, own calculations. 
Table A3 Robustness of Mincer-type Wage Regression

\begin{tabular}{|c|c|c|c|}
\hline VARIABLES & $(10)$ & (10a) & $(10 \mathrm{~b})$ \\
\hline Experience & $\begin{array}{l}0.019 * * * \\
(0.00081)\end{array}$ & $\begin{array}{l}0.019 * * * \\
(0.00062)\end{array}$ & $\begin{array}{l}0.019 * * * \\
(0.00081)\end{array}$ \\
\hline Experience Squared & $\begin{array}{c}-0.00041 * * * \\
(0.000017)\end{array}$ & $\begin{array}{c}-0.00041 * * * \\
(0.000014)\end{array}$ & $\begin{array}{c}-0.00041^{* * *} \\
-0.00002\end{array}$ \\
\hline Medium Education & $\begin{array}{c}0.045^{* * *} \\
(0.0079)\end{array}$ & $\begin{array}{c}0.052 * * * \\
(0.0063)\end{array}$ & $\begin{array}{c}0.045^{* * *} \\
(0.0093)\end{array}$ \\
\hline Migrant with Medium Education & $\begin{array}{l}-0.022 \\
(0.014)\end{array}$ & $\begin{array}{c}-0.049^{* * *} \\
(0.010)\end{array}$ & $\begin{array}{l}-0.022 \\
(0.012)\end{array}$ \\
\hline High Education & $\begin{array}{l}0.10^{* * *} \\
(0.011)\end{array}$ & $\begin{array}{l}0.10^{* * *} \\
(0.0086)\end{array}$ & $\begin{array}{l}0.10^{* * * *} \\
(0.014)\end{array}$ \\
\hline Migrant with High Education & $\begin{array}{c}-0.085^{* * *} \\
(0.024)\end{array}$ & $\begin{array}{c}-0.11 * * * \\
(0.019)\end{array}$ & $\begin{array}{c}-0.085^{* * * *} \\
(0.023)\end{array}$ \\
\hline High Education Job Match & $\begin{array}{l}0.22 * * * \\
(0.010)\end{array}$ & $\begin{array}{l}0.23 * * * \\
(0.0080)\end{array}$ & $\begin{array}{l}0.22 * * * \\
(0.015)\end{array}$ \\
\hline Migrant with High Education Job Match & $\begin{array}{l}0.060 * \\
(0.033)\end{array}$ & $\begin{array}{c}0.061 * * \\
(0.026)\end{array}$ & $\begin{array}{c}0.060 * * \\
(0.023)\end{array}$ \\
\hline Female & $\begin{array}{l}-0.11 * * * \\
(0.0061)\end{array}$ & $\begin{array}{l}-0.12 * * * \\
(0.0046)\end{array}$ & $\begin{array}{l}-0.11 * * * \\
(0.0052)\end{array}$ \\
\hline Unemployment Experience & $\begin{array}{c}-0.024 * * * \\
(0.0019)\end{array}$ & $\begin{array}{c}-0.025^{* * *} \\
(0.0015)\end{array}$ & $\begin{array}{c}-0.024 * * * \\
(0.0020)\end{array}$ \\
\hline Trained for Job & $\begin{array}{l}0.021 * * * \\
(0.0048)\end{array}$ & $\begin{array}{l}0.022 * * * \\
(0.0039)\end{array}$ & $\begin{array}{l}0.021 * * * \\
(0.0066)\end{array}$ \\
\hline Autonomy (Job Type) & $\begin{array}{l}0.11 * * * \\
(0.0030)\end{array}$ & $\begin{array}{l}0.11 * * * \\
(0.0024)\end{array}$ & $\begin{array}{l}0.11 * * * \\
(0.0050)\end{array}$ \\
\hline Migrant & $\begin{array}{c}-0.12 * * * \\
(0.030)\end{array}$ & $\begin{array}{c}-0.076^{* * *} \\
(0.019)\end{array}$ & $\begin{array}{c}-0.12 * * * \\
(0.031)\end{array}$ \\
\hline Years in Germany & $\begin{array}{c}0.0068 * * * \\
(0.0024)\end{array}$ & $\begin{array}{c}0.0070 * * * \\
(0.0015)\end{array}$ & $\begin{array}{l}0.0068 * \\
(0.0034)\end{array}$ \\
\hline Years in Germany Squared & $\begin{array}{c}-0.00014 * * * \\
(0.000053)\end{array}$ & $\begin{array}{c}-0.00013 * * * \\
(0.000034)\end{array}$ & $\begin{array}{l}-0.00014^{*} \\
(0.000070)\end{array}$ \\
\hline German Writing Literacy Good or Very Good & $\begin{array}{c}0.051^{* * * *} \\
(0.018)\end{array}$ & $\begin{array}{c}0.042^{* * * *} \\
(0.012)\end{array}$ & $\begin{array}{c}0.051 * * \\
(0.019)\end{array}$ \\
\hline German Degree & $\begin{array}{l}0.0060 \\
(0.013)\end{array}$ & $\begin{array}{l}-0.00057 \\
(0.0094)\end{array}$ & $\begin{array}{l}0.0060 \\
(0.013)\end{array}$ \\
\hline Born in Advanced Country & $\begin{array}{c}0.052 * * * \\
(0.015)\end{array}$ & $\begin{array}{l}0.020 * * \\
(0.0090)\end{array}$ & $\begin{array}{c}0.052 * * * \\
(0.0071)\end{array}$ \\
\hline Migrated after 2007 & $\begin{array}{c}-0.17 * * * \\
(0.057) \\
\end{array}$ & $\begin{array}{c}-0.080 * * * \\
(0.030) \\
\end{array}$ & $\begin{array}{l}-0.17 * * \\
(0.050)\end{array}$ \\
\hline Controls & YES & YES & YES \\
\hline Observations & 224,272 & 224,272 & 224,272 \\
\hline R-squared & 0.407 & 0.434 & 0.407 \\
\hline
\end{tabular}

Robust standard errors in parentheses; *** $\mathrm{p}<0.01, * * \mathrm{p}<0.05, * \mathrm{p}<0.1$

As controls I include the region, whether the person is married, works full time,

the age and the number of years in the firm, as well as year and industry dummies.

Note: (10) is identical to (10) in Table 2; (10a) and (10b) estimate the same model with different methodologies. Source: SOEP 1984-2013, own calculations. 